University of New Hampshire

University of New Hampshire Scholars' Repository

Faculty Publications

$10-10-2017$

\title{
Nitrification increases nitrogen export from a tropical river network
}

\author{
Lauren E. Koenig \\ University of Connecticut, Storrs \\ Chao Song \\ University of Georgia \\ Wilfred M. Wollheim \\ University of New Hampshire, Durham, wil.wollheim@unh.edu \\ Janine Ruegg \\ École Polytechnique Fédérale de Lausanne \\ William H. McDowell \\ University of New Hampshire, Durham, bill.mcdowell@unh.edu
}

Follow this and additional works at: https://scholars.unh.edu/faculty_pubs

\section{Comments}

This is an article published by University of Chicago Press in Freshwater Science in 2017, available online:

https://dx.doi.org/10.1086/694906

\section{Recommended Citation}

Koenig L.E., C. Song, W.M. Wollheim, J. Ruegg, W.H. McDowell. 2017. Nitrification increases nitrogen export from a tropical river network. Freshwater Science. 2017. 36(4):DOI: 10.1086/694906.

This Article is brought to you for free and open access by University of New Hampshire Scholars' Repository. It has been accepted for inclusion in Faculty Publications by an authorized administrator of University of New Hampshire Scholars' Repository. For more information, please contact Scholarly.Communication@unh.edu. 


\title{
Nitrification increases nitrogen export from a tropical river network
}

\author{
Lauren E. Koenig ${ }^{1,4}$, Chao Song ${ }^{2,5}$, Wilfred M. Wollheim ${ }^{1,6}$, Janine Rüegg ${ }^{3,7}$, \\ and William H. McDowell ${ }^{1,8}$ \\ ${ }^{1}$ Department of Natural Resources and the Environment, University of New Hampshire, Durham, New Hampshire 03824 USA \\ ${ }^{2}$ Odum School of Ecology, University of Georgia, Athens, Georgia 30602 USA \\ ${ }^{3}$ Stream Biofilm and Ecosystem Research, École Polytechnique Fédérale de Lausanne, 1015 Lausanne, Switzerland
}

\begin{abstract}
Scaling aquatic ecosystem processes like nutrient removal is critical for assessing the importance of streams and rivers to watershed nutrient export. We used pulse $\mathrm{NH}_{4}{ }^{+}$enrichment experiments and measured net $\mathrm{NH}_{4}{ }^{+}$uptake in 7 streams throughout a mountainous tropical river network in Puerto Rico to assess spatial variability in $\mathrm{NH}_{4}{ }^{+}$uptake and to infer the physical, chemical, and biological characteristics that most influence its variation. Across 14 experiments, $\mathrm{NH}_{4}{ }^{+}$uptake velocity $\left(v_{\mathrm{f}}\right)$ ranged from 0.3 to 8.5 (mean $\left.=2.7\right) \mathrm{mm} / \mathrm{min}$ and was positively related to algal biomass standing stock, measured as chlorophyll $a$. On average, $49 \%$ of experimentally added $\mathrm{NH}_{4}{ }^{+}$was immediately transformed to $\mathrm{NO}_{3}{ }^{-}$, suggesting that nitrification can rival microbial and algal assimilation as a fate of streamwater $\mathrm{NH}_{4}{ }^{+}$. We considered the implications of our empirical results at the river-network scale based on a simple mass-balance model parameterized for the Río Mameyes watershed. Most catchment $\mathrm{NH}_{4}{ }^{+}$inputs are delivered to $1^{\text {st }}$-order streams. Therefore, model results indicated that high $\mathrm{NH}_{4}{ }^{+}$uptake rates in headwater streams limit $\mathrm{NH}_{4}{ }^{+}$inputs to downstream reaches, thereby decreasing the role of larger streams in $\mathrm{NH}_{4}{ }^{+}$removal at the river-network scale. In-stream nitrification resulted in additional $\mathrm{NO}_{3}{ }^{-}$inputs, which were more likely than $\mathrm{NH}_{4}{ }^{+}$to be transported downstream because of lower biological demand for $\mathrm{NO}_{3}{ }^{-}$relative to $\mathrm{NH}_{4}{ }^{+}$. Given our estimates of catchment $\mathrm{N}$ loading to streams and rivers, we estimated that $39 \%$ of modeled watershed $\mathrm{NO}_{3}{ }^{-}$export was produced within the river network by nitrification. Together, these results suggest that streams and rivers can significantly transform the $\mathrm{N}$ load from their catchments.

Key words: nitrification, nutrient spiraling, ammonium uptake, river network model, gross primary production, TASCC, tropical, stream, Puerto Rico
\end{abstract}

Streams and rivers receive, transport, and actively process energy and nutrient loads from the terrestrial landscape. River networks hydrologically connect the terrestrial environment to downstream lakes, estuaries, and the coastal ocean and regulate watershed nutrient delivery and export (Howarth et al. 1996, Peterson et al. 2001, Wollheim et al. 2008b). Therefore, evaluating the landscape characteristics and biological processes that affect the magnitude and spatial distribution of aquatic nutrient removal is critical to understanding how streams and rivers modulate delivery of nutrients to downstream ecosystems.

The role of aquatic nutrient removal in influencing watershed nutrient export depends on the fate of nutrients. Nutrient consumption and uptake in fluvial ecosystems can result in temporary storage through cycles of biotic as- similation and remineralization, long-term retention or permanent removal (e.g., abiotic sorption, burial, or denitrification) (Triska et al. 1994, Ashkenas et al. 2004, Mulholland et al. 2008), or may simply transform one nutrient species into another (e.g., nitrification). Nutrient uptake in streams is influenced by nutrient availability (Dodds et al. 2002, Earl et al. 2006, Mulholland et al. 2008), hydrology and stream geomorphology (Valett et al. 1996, Hall et al. 2002), aquatic primary productivity (Hall and Tank 2003, Newbold et al. 2006), and C availability (Bernhardt and Likens 2002, Dodds et al. 2004, Rodríguez-Cardona et al. 2016). These drivers can be used to predict how aquatic nutrient removal might vary with ecosystem size or network position (Stream Solute Workshop 1990), but most inferences of the controls on nutrient uptake come from studies of individual streams

E-mail addresses: ${ }^{4}$ lauren.koenig@unh.edu; ${ }^{5}$ chaosong@uga.edu; ${ }^{6}$ wil.wollheim@unh.edu; ${ }^{7}$ janine.ruegg@epfl.ch; ${ }^{8}$ bill.mcdowell@unh.edu

DOI: 10.1086/694906. Received 2 January 2017; Accepted 18 August 2017; Published online 10 October 2017.

Freshwater Science. 2017. 36(4):698-712. () 2017 by The Society for Freshwater Science. 
and rivers across different watersheds, land uses, and biomes (Peterson et al. 2001, Hall et al. 2009). As a result, a fundamental understanding of the patterns and controls on nutrient uptake within individual river networks is lacking (Ensign and Doyle 2006), and it remains difficult to scale aquatic ecosystem processes from individual stream reaches to whole river networks and infer the role of aquatic ecosystems in global nutrient cycles (Wollheim et al. 2008b).

These scaling challenges are exacerbated in tropical environments, where fewer studies of aquatic nutrient cycling have been conducted compared to temperate ecosystems. Anthropogenic $\mathrm{N}$ deposition and $\mathrm{N}$ inputs from urbanization are increasing throughout the tropics (Downing et al. 1999, Matson et al. 1999). Therefore, understanding $\mathrm{N}$ removal in river networks is important for predicting the effects of anthropogenic activities on watershed $\mathrm{N}$ export, especially in tropical mountainous watersheds like those in Puerto Rico, where short transit times from land to the ocean make downstream estuaries vulnerable to eutrophication (Ortiz-Zayas et al. 2006). We know from previous research in Puerto Rico that stream $\mathrm{NO}_{3}{ }^{-}$uptake rates are relatively low across streams draining forested, agricultural, and urban lands, but that $\mathrm{NO}_{3}{ }^{-}$uptake increases with aquatic gross primary production (Potter et al. 2010). In addition, nitrification is thought to be an important fate of streamwater $\mathrm{NH}_{4}{ }^{+}$, as reported by Merriam et al. (2002) for one stream in northeastern Puerto Rico. However, no research to date has investigated the spatial variability in either stream $\mathrm{NH}_{4}{ }^{+}$uptake or the relative importance of instream nitrification to $\mathrm{NH}_{4}{ }^{+}$uptake in these river networks, which contain considerable heterogeneity in their topography, underlying geology, and hydrologic flowpaths over relatively small watershed areas (Pike et al. 2010, McDowell et al. 1992, 2012).

The primary objectives of our study were to examine the spatial variability in stream $\mathrm{NH}_{4}{ }^{+}$uptake and nitrification in a tropical mountain river network in Puerto Rico and to use a mass-balance model to analyze the implications of measured $\mathrm{N}$ uptake rates for the spatial distribution of $\mathrm{N}$ removal at the river-network scale. We predicted that $\mathrm{NH}_{4}{ }^{+}$uptake would increase with stream metabolism, notably gross primary productivity (GPP), which should increase biological demand for $\mathrm{N}$ in streams with sufficient light availability. Furthermore, we expected that the relative importance of nitrification to stream $\mathrm{NH}_{4}{ }^{+}$uptake would be highest in shaded headwaters, where streams may be energy-limited by lack of light inputs, high rates of decomposition, and low dissolved organic C (DOC) concentrations (Merriam et al. 2002, Helton et al. 2015). Better understanding of the patterns in $\mathrm{N}$ uptake and the processes influencing its variation within individual river networks will contribute to development of ecological scaling relationships that inform the fate of energy and nutrients in catchments.

\section{METHODS}

\section{Study sites}

This study was conducted in the Luquillo Experimental Forest in northeastern Puerto Rico (Fig. 1). We selected seven $1^{\text {st }}$ - to $3^{\text {rd }}$-order streams within the upper Río Mameyes watershed. Mean daily air temperature in the Luquillo mountains ranges from 19 to $26^{\circ} \mathrm{C}$ and annual precipitation ranges from 2500 to $4500 \mathrm{~mm} / \mathrm{y}$, with greater rainfall observed at higher elevations (100-1000 m asl) (Brown et al. 1983). The months of January to April typically have lower rainfall than the rest of the year (Heartsill-Scalley et al. 2007), but these tropical forests are not characterized by marked seasonality in precipitation, soil-solution chemistry, or stream chemistry (McDowell 1998, McDowell et al. 2012). The dominant soils are highly weathered, clay-rich
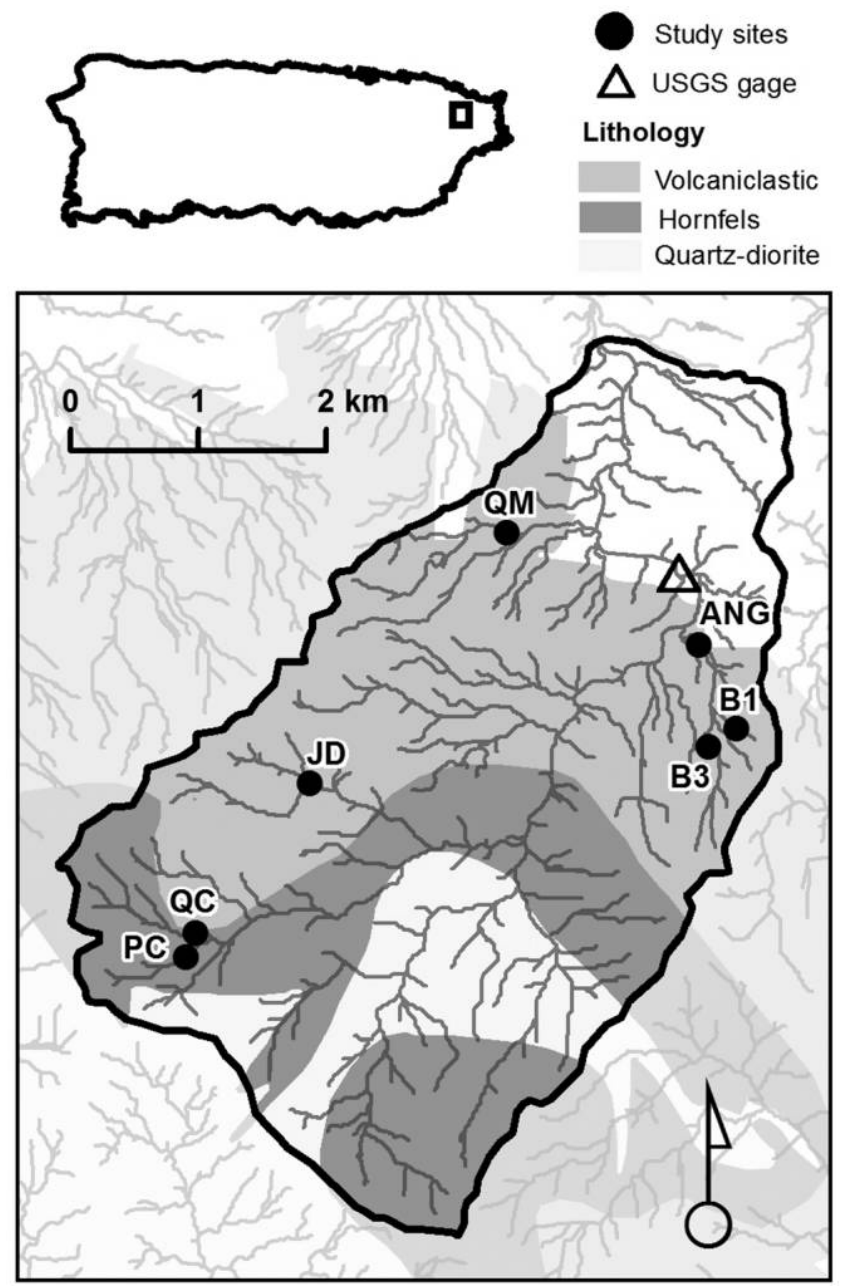

Figure 1. Location of study sites within the upper Río Mameyes network, Puerto Rico. B1 = Bisley 1, B3 = Bisley 3, ANG $=$ Angelito, $\mathrm{PC}=$ Piscina, $\mathrm{JD}=$ Juan Diego, $\mathrm{QM}=$ Máquina, and QC $=$ Caimitillo. The hollow triangle denotes the location of the US Geological Survey gaging station on the Río Mameyes (USGS 50065500). 
Ultisols, Inceptisols, and Oxisols that generally lack a conspicuous organic horizon (Silver et al. 1999).

Our study streams were heavily shaded but varied in aspect, catchment topography, and geology depending on their position in the watershed (Table 1). Four streams were situated in the western headwaters at higher elevation (300-800 m asl). Two of these streams drain hornfels facies, outcrops of contact metamorphosed volcaniclastic bedrock. Three streams were situated at lower elevation and drained north-facing slopes underlain by unmetamorphosed volcaniclastic bedrock, which is less resistant to erosion than the hornfels facies rock (Fig. 1) (Pike et al. 2010). Three of the 7 streams were identified as intensive study sites where we replicated our $\mathrm{NH}_{4}{ }^{+}$enrichment experiments (described in detail below) in 2 reaches (Bisley 1, Bisley 3, Angelito) or at 2 points in time during a 6 -wk period (Bisley 1 , Bisley 3 ) to assess within-stream variability in $\mathrm{NH}_{4}{ }^{+}$uptake. In each of the 7 streams, we chose study reaches that contained no tributary inflows and had a mean hydrologic travel time between 20 and $60 \mathrm{~min}$ to ensure sufficient distance and time for proper mixing and detectable uptake of solutes. The resulting reach lengths were typical of small streams (40-80 m; Webster and Valett 2006).

\section{Stream metabolism and algal biomass}

We estimated whole-stream metabolism for each stream reach by measuring changes in dissolved $\mathrm{O}_{2}$ concentration (DO), water temperature, and light intensity at 10-min intervals over 1 - to 5 -d deployment periods with YSI (Yellow Springs Instruments, Yellow Springs, Ohio) ProODO optical dissolved $\mathrm{O}_{2}$ sondes and Odyssey (Christchurch, New Zealand) light loggers. We estimated daily gross primary production (GPP) and ecosystem respiration (ER) rates by fitting a 1-station Lagrangian model to diel $\mathrm{O}_{2}$ curves. We modified the approach taken by Riley and Dodds (2013) by describing the temperature dependence of GPP and ER with an Arrhenius equation, and we used a Bayesian approach with a uniform prior distribution to estimate daily rates of GPP and ER (Song et al. 2016). For multiday deployments, we allowed parameters (GPP, ER, and the gas-exchange coefficient $\left[K-\mathrm{O}_{2}\right]$ ) to vary from day to day, but we assumed that $K-\mathrm{O}_{2}$ is relatively constant between days if flow conditions do not change dramatically. Therefore, for days where GPP, ER, and $\mathrm{K}-\mathrm{O}_{2}$ were not uniquely estimable, we constructed a gamma distribution based on $\mathrm{K}-\mathrm{O}_{2}$ estimated from other deployment days in the same stream and used it as the prior distribution for $K-\mathrm{O}_{2}$.

Logistical constraints required that we offset our stream metabolism measurements by as much as 3 to $9 \mathrm{~d}$ at 3 study sites (Piscina, Juan Diego, and Caimitillo). We present the metabolism data from these sites because no significant precipitation occurred between the metabolism and nutrient uptake measurements, and because climatic conditions, such as light and air temperature, remained similar (González 2015). In 3 other streams where multiday deployments overlapped the offset time period in Piscina, Juan Diego, and Caimitillo, variability in daily stream metabolism was lower than variability observed over the 6-wk experimental window (e.g., Bisley 1 reach 1, GPP CV $=68 \%$ during overlapping offset period; $\mathrm{CV}=119 \%$ all observations; LEK, unpublished data). Therefore, we included stream metabolism data for Piscina, Juan Diego, and Caimitillo, but we acknowledge that short-term variability in daily GPP and ER at these sites may limit this comparison. In 6 of the 7 stream sites, we measured chlorophyll $a(\mathrm{Chl} a)$ standing stock once within 0 to $4 \mathrm{~d}$ of the nutrient-enrichment experiment as a proxy for autotrophic biomass. We sampled benthic substrata for Chl $a$ at 10 evenly spaced transects throughout the stream reach either by scraping biofilm from a known surface area or by whole-rock extraction (Murdock and Dodds 2007). We analyzed Chl $a$ after hot-ethanol extraction on a Thermo Scientific (Waltham, MA) Genesys 6 spectrophotometer (Sartory and Grobbelaar 1984) and corrected for acidification time (Parker et al. 2016).

\section{Nutrient-enrichment experiments}

We performed $14 \mathrm{NH}_{4}{ }^{+}$enrichment experiments in 7 streams during January to March 2013. Prior to each reach-scale experiment, we collected background samples

Table 1. Physical characteristics of study streams in the Luquillo Experimental Forest. VC $=$ unmetamorphosed volcaniclastic bedrock, $\mathrm{HF}=$ hornfels facies (contact metamorphosed volcaniclastic bedrock).

\begin{tabular}{lcccccc}
\hline \multicolumn{1}{c}{ Study site } & $\begin{array}{c}\text { Stream } \\
\text { order }\end{array}$ & $\begin{array}{c}\text { Bedrock } \\
\text { lithology }\end{array}$ & $\begin{array}{c}\text { Upstream area } \\
\left(\mathrm{km}^{2}\right)\end{array}$ & $\begin{array}{c}\text { Streambed } \\
\text { slope }\left(^{\circ}\right)\end{array}$ & $\begin{array}{c}\text { Mean catchment } \\
\text { slope }\left(^{\circ}\right)\end{array}$ & $\begin{array}{c}\text { Mean canopy } \\
\text { cover }(\%)\end{array}$ \\
\hline Bisley 1 & 1 & VC & 0.07 & 13.2 & 27.9 & 95 \\
Bisley 3 & 2 & VC & 0.35 & 13.1 & 27.9 & 94 \\
Angelito & 2 & VC & 0.40 & 8.9 & 25.0 & 93 \\
Piscina & 2 & HF & 0.31 & 12.5 & 20.2 & 77 \\
Juan Diego & 2 & VC & 0.50 & 12.4 & 36.1 & 85 \\
Máquina & 3 & VC & 0.68 & 14.1 & 26.9 & 86 \\
Caimitillo & 2 & HF & 0.50 & 13.7 & 18.3 & 88 \\
\hline
\end{tabular}


of stream water for chemical analyses and measured stream discharge by dilution-gauging of short-term $\mathrm{NaCl}$ releases (Kilpatrick and Cobb 1985, Payn et al. 2009). We monitored specific conductance to ensure that $\mathrm{Cl}^{-}$concentrations had returned to background levels between $\mathrm{NaCl}$ dilution-gauging releases and nutrient-enrichment experiments.

During each experiment we added reactive $\mathrm{NH}_{4}{ }^{+}$(as $\mathrm{NH}_{4} \mathrm{Cl}$ ) and a conservative tracer (as $\mathrm{NaCl}$ ) to the stream as a single, pulse addition (Tank et al. 2008, Covino et al. 2010). We collected 20 to 35 samples over time (solute breakthrough curves) at the downstream end of each reach, where we monitored specific conductance with a YSI 556 conductivity probe logging at 5-s intervals. We filtered samples in the field through a $0.7-\mu \mathrm{m}$ filter (Whatman GF/F) into 60-mL, acid-washed, high-density polyethylene (HDPE) bottles and shipped them frozen to the Water Quality Analysis Laboratory at the University of New Hampshire. Samples were analyzed for: 1) $\mathrm{NH}_{4}{ }^{+}-\mathrm{N}$ by the phenol-hypochlorite method (Solórzano 1969) on a Westco (Brookfield, Connecticut) SmartChem 200 discrete auto-analyzer, 2) $\mathrm{Cl}^{-}$with a Dionex (Waltham, Massachusetts) ICS-1000 ion chromatograph, and 3) $\mathrm{NO}_{3}{ }^{-}-\mathrm{N}$ with the Cdreduction technique on a Seal Analytical (Mequon, Wisconsin) discrete auto-analyzer. Background water-chemistry samples also were analyzed for DOC and total dissolved $\mathrm{N}$ (TDN) by the high temperature catalytic oxidation method on a Shimadzu (Columbia, Maryland) TOC-V CPH with TNM N unit. We calculated dissolved organic N (DON) by subtracting dissolved inorganic $\mathrm{N}\left(\mathrm{DIN}=\mathrm{NO}_{3}{ }^{-}+\mathrm{NH}_{4}{ }^{+}\right)$ from measured TDN concentrations.

\section{Estimating $\mathrm{NH}_{4}{ }^{+}$uptake and $\mathrm{NO}_{3}{ }^{-}$production}

We used 2 approaches to assess stream response to experimental $\mathrm{NH}_{4}{ }^{+}$enrichments and to estimate rates of $\mathrm{NH}_{4}{ }^{+}$ uptake. For each approach, we quantified nutrient-spiraling parameters from the breakthrough curve of added solutes, including the areal $\mathrm{NH}_{4}{ }^{+}$uptake rate $\left(U ; \mu \mathrm{g} \mathrm{N} \mathrm{m}{ }^{-2} \min ^{-1}\right)$ and $\mathrm{NH}_{4}{ }^{+}$uptake velocity $\left(v_{\mathrm{f}} ; \mathrm{mm} \mathrm{N} / \mathrm{min}\right)$, which represents uptake relative to $\mathrm{NH}_{4}{ }^{+}$availability (Stream Solute Workshop 1990). We estimated $U$ of added $N$ (hereafter referred to as net uptake $\left[U_{\text {net }}\right]$; Payn et al. 2005) for each sample across the breakthrough curve by using an approach modified from the tracer addition for spiraling curve characterization (TASCC) method (Covino et al. 2010). We calculated the $1^{\text {st }}$-order kinetic rate $\left(K_{t} ; 1 / \mathrm{min}\right)$ for each sample by assuming an exponential decline in nutrient concentration over the stream reach (Stream Solute Workshop 1990):

$$
K_{t}=\frac{\ln \left(\frac{N_{I N J}}{C l_{I N I}}\right)-\ln \left(\frac{N_{B C}}{C l_{B C}}\right)}{t},
$$

where $N_{I N J}, C l_{I N J}, N_{B C}$, and $C l_{B C}$ are the $\mathrm{NH}_{4}{ }^{+}-\mathrm{N}$ and $\mathrm{Cl}^{-}$ concentrations of the injected solution and the backgroundcorrected $\mathrm{NH}_{4}{ }^{+}-\mathrm{N}$ and $\mathrm{Cl}^{-}$concentrations of each sample, respectively, and $t$ is time elapsed since injection of the nutrient solution. Our use of Eq. 1 enabled us to account for variable travel times rather than using a single, average residence time throughout the breakthrough curve. This approach was advantageous because a single, average residence time likely is not representative of our study streams and relatively short reach lengths.

We converted $K_{t}$ for each sample to net $v_{\mathrm{f}}$ and $U_{n e t}$ :

$$
\begin{gathered}
v_{f \text { net }}=K_{t} z, \\
U_{\text {net }}=v_{f \text { net }} N_{a d d}, \\
N_{\text {add }}=\sqrt{N_{\text {cons }} N_{B C}},
\end{gathered}
$$

where $z$ is reach-averaged depth and $N_{\text {add }}$ represents the reach-averaged concentration of added $\mathrm{NH}_{4}{ }^{+}$for a given sample, calculated as the geometric mean of the background-corrected $\mathrm{NH}_{4}{ }^{+}$concentration and the estimated $\mathrm{NH}_{4}{ }^{+}$concentration given conservative transport ( $N_{\text {cons }} ;$ Eq. 4). We calculated $N_{\text {cons }}$ by multiplying the background-corrected $\mathrm{Cl}^{-}$concentration by the $\mathrm{NH}_{4}{ }^{+}: \mathrm{Cl}^{-}$ ratio of the injected solution. We used the geometric mean to represent the added nutrient concentration during the experiment because the background-corrected $\mathrm{NH}_{4}{ }^{+}$concentration at the measurement location probably underestimates the $\mathrm{N}$ concentration experienced by stream biofilms along the length of the experimental reach. In this sense, the geometric mean concentration represents a best approximation of background-corrected $\mathrm{NH}_{4}{ }^{+}$concentration throughout the stream reach during the enrichment experiment (Covino et al. 2010). For each experiment, we used the slope of the best-fit line between $U_{n e t}$ and the total reachaveraged $\mathrm{NH}_{4}{ }^{+}$concentration in each sample $\left(N_{\text {total }}\right)$, equal to the sum of background $\mathrm{NH}_{4}{ }^{+}-\mathrm{N}$ concentration and $N_{a d d}$, to estimate the average net $v_{\mathrm{f}}$. Use of this approach carried the inherent assumption that net $v_{\mathrm{f}}$ is constant with concentration (i.e., $1^{\text {st }}$-order kinetics), and therefore, net $\mathrm{NH}_{4}{ }^{+} v_{\mathrm{f}}$ represents a reach-averaged $v_{\mathrm{f}}$ during the experiment.

We also used a transport-based modeling approach to estimate $\mathrm{NH}_{4}{ }^{+}$uptake. We observed significant hysteresis in the relationship between $U_{n e t}$ and reach-averaged $\mathrm{NH}_{4}{ }^{+}$ concentration during all of our pulse nutrient-enrichment experiments (Fig. 2). This consistent pattern suggested that $\mathrm{NH}_{4}{ }^{+} U_{\text {net }}$ might vary with flowpath in our study reaches and motivated our use of an advection-dispersion modeling approach to estimate separate $\mathrm{NH}_{4}{ }^{+}$uptake rates for the stream channel and transient storage zone, respectively. We used a 1-dimensional advection-dispersion model with transient storage, and assumed $1^{\text {st }}$-order uptake kinetics (Stream Solute Workshop 1990, Runkel 2007). Specifically, we modeled solute dynamics as: 


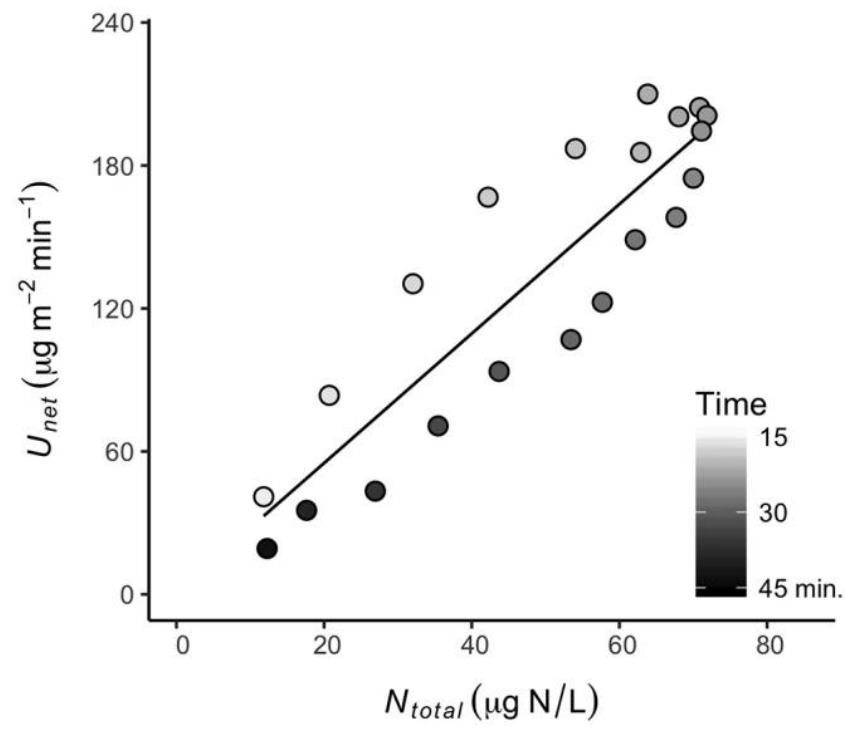

Figure 2. The relationship between net $\mathrm{NH}_{4}{ }^{+}$uptake rate $\left(U_{\text {net }}\right)$ and total reach-averaged $\mathrm{NH}_{4}{ }^{+}$concentration $\left(N_{\text {total }}\right)$, where sample shading indicates the elapsed time since injection of the nutrient solution. Clockwise hysteresis was observed during each of the 14 individual experiments (Angelito reach 2, February 2013 shown here).

$$
\begin{gathered}
\frac{\partial C}{\partial t}=-V \frac{\partial C}{\partial x}+D \frac{\partial^{2} C}{\partial x^{2}}-\alpha\left(C-C_{t s}\right)-K C, \\
\frac{d C_{t s}}{d t}=\frac{A}{A_{s}} \alpha\left(C-C_{t s}\right)-K_{t s} C_{t s}
\end{gathered}
$$

where $C$ and $C_{t s}$ are solute concentration in the main channel and transient storage zone, respectively, $V$ is mean stream velocity, $x$ is longitudinal distance, $D$ is the dispersion coefficient, and $\alpha$ is the exchange rate between the main channel and the transient storage zone. $A$ and $A_{s}$ represent the cross-sectional area of the stream channel and transient storage zone, and $K$ and $K_{t s}$ represent the $1^{\text {st }}$-order kinetic rate $(1 / \mathrm{min})$ in the main channel and transient storage zone, respectively.

We fit the advection-dispersion model separately to the $\mathrm{NH}_{4}{ }^{+}$and $\mathrm{Cl}^{-}$breakthrough curves to estimate best-fit values for the relative size of transient storage $\left(A_{s} / A\right)$, the storage exchange-rate coefficient $(\alpha)$, and the $1^{\text {st }}$-order kinetic rates for the main stream channel $(K)$ and transient storage zone $\left(K_{t s}\right)$, respectively. We solved the model numerically for any set of parameter values and fit the model to the observed breakthrough curve using nonlinear least squares. We used the ReacTran package in $\mathrm{R}$ (Soetaert and Meysman 2012) to simulate the advection-dispersion model and used a modified Levenberg-Marquardt algorithm implemented in the nlmrt package (Nash 1990) to estimate the hydrologic and biologic parameter values that best fit the observed tracer data. We then used the optimized solute transport simulations to calculate the mean transient storage zone residence time for each stream reach $\left(T_{s}\right)$ as $A_{s} /(A \times \alpha)$ (Harvey and Wagner 2000).

We also estimated relative rates of $\mathrm{NO}_{3}{ }^{-}$production during the $\mathrm{NH}_{4}{ }^{+}$addition experiment by integrating the area under the breakthrough curve of observed $\mathrm{NO}_{3}{ }^{-}$concentration over time. We calculated the percentage of added $\mathrm{NH}_{4}{ }^{+}$that was immediately nitrified as:

$$
\% \mathrm{NH}_{4}{ }^{+} \text {nitrified }=\frac{N O_{3 R E C}}{N H_{4 I N J}-N H_{4 R E C}} \times 100,
$$

where $\mathrm{NO}_{3 R E C}$ is the mass of background-corrected $\mathrm{NO}_{3}{ }^{-}-\mathrm{N}$ recovered at the downstream sampling station, $\mathrm{NH}_{4 I N J}$ is the mass of $\mathrm{NH}_{4}{ }^{+}-\mathrm{N}$ injected, and $\mathrm{NH}_{4 R E C}$ is the mass of background-corrected $\mathrm{NH}_{4}{ }^{+}-\mathrm{N}$ recovered at the downstream sampling station during the experiment (sensu Snyder and Bowden 2014). Estimates of $\% \mathrm{NH}_{4}{ }^{+}$nitrified based on Eq. 7 represent net nitrification and, therefore, are conservative because we do not account for any $\mathrm{NO}_{3}{ }^{-}$that may have been consumed in the stream reach.

\section{Statistical analyses}

We used net $\mathrm{NH}_{4}{ }^{+} v_{\mathrm{f}}$ to compare $\mathrm{NH}_{4}{ }^{+}$uptake rates across streams because $v_{\mathrm{f}}$ enables comparison of streams with different hydrologic characteristics and background N concentrations (Hall et al. 2002, Ensign and Doyle 2006). We present results from the advection-dispersion model method because estimates of net $v_{\mathrm{f}}$ were similar between the 2 approaches presented above (Table 2) and because the advection-dispersion method enabled us to isolate $\mathrm{NH}_{4}{ }^{+}$uptake in the main stream channel (hereafter, net stream $\mathrm{NH}_{4}{ }^{+} v_{\mathrm{f}}$ ) and in transient storage zones. We used Pearson correlations to relate net stream $\mathrm{NH}_{4}{ }^{+} v_{\mathrm{f}}$ and \% $\mathrm{NH}_{4}{ }^{+}$nitrified to physical, chemical, and biological variables that we hypothesized would influence their variation in streams draining the Luquillo Mountains. We examined bivariate relationships between net stream $\mathrm{NH}_{4}{ }^{+} v_{\mathrm{f}}$ and \% $\mathrm{NH}_{4}{ }^{+}$nitrified and 9 potential covariates, including light intensity, $T_{s}, \mathrm{GPP}, \mathrm{ER}, \mathrm{Chl} a$, and $\mathrm{N}$ and $\mathrm{C}$ availability (as $\mathrm{NO}_{3}{ }^{-}$, DON, DOC, and the DOC : DIN molar ratio). To avoid bias toward the intensive study sites where nutrient-addition experiments were performed in multiple reaches, we averaged values for $v_{\mathrm{f}}, \% \mathrm{NH}_{4}{ }^{+}$nitrified, and all covariates when experiments were performed in multiple reaches within a stream on the same day (resulting in $n=9$ ). All statistical analyses were conducted in R (version 3.3.2; R Project for Statistical Computing, Vienna, Austria).

\section{River-network $\mathbf{N}$ dynamics and export}

Our $2^{\text {nd }}$ objective was to analyze the implications of our empirical results at the river-network scale. We applied an $\mathrm{N}$ mass-balance model to a statistical representation of the $5^{\text {th }}$-order Río Mameyes network following the approach described by Wollheim et al. (2006), although we added an 


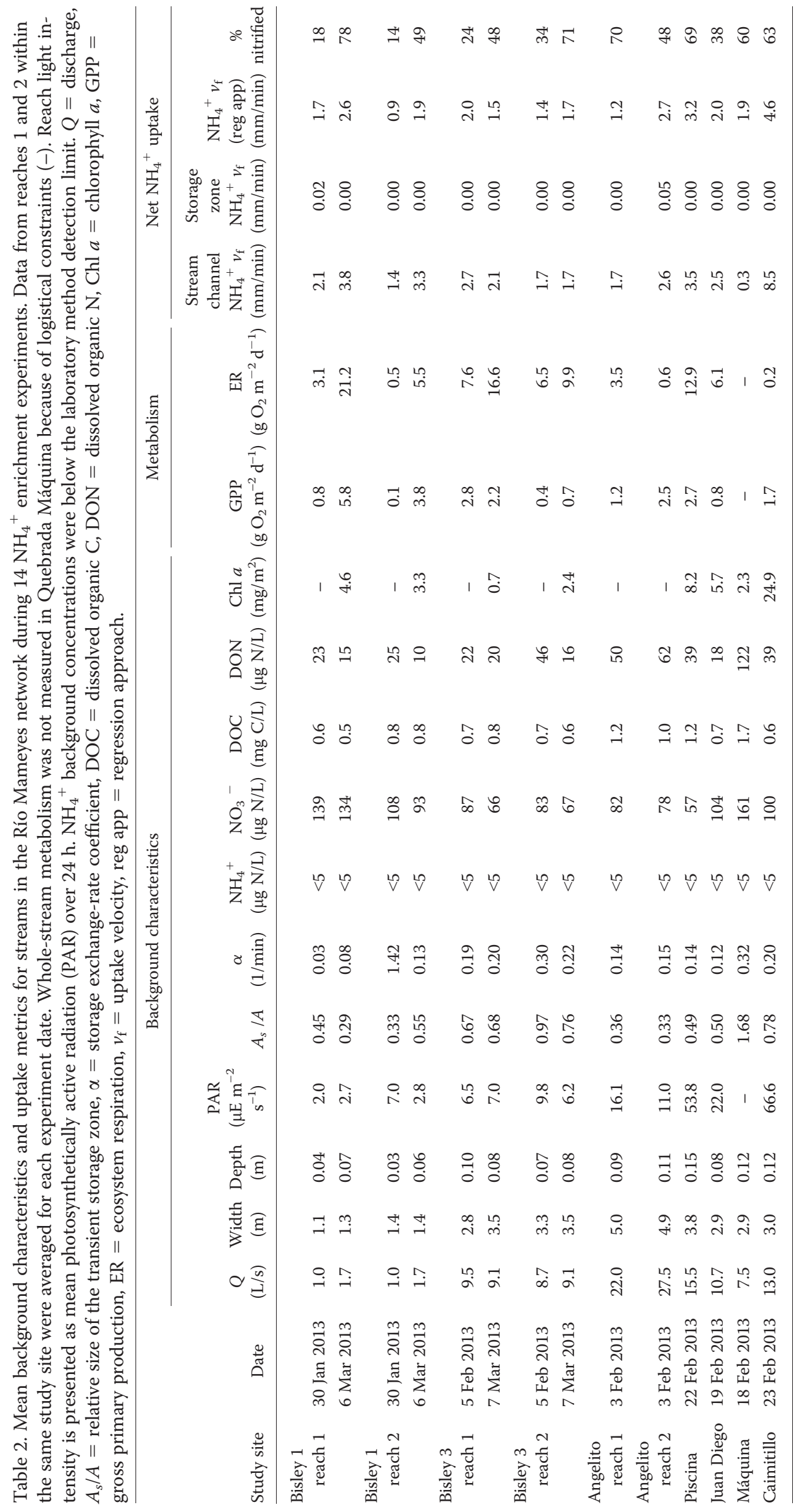


additional source of $\mathrm{NO}_{3}{ }^{-}$from in-stream nitrification. We estimated mean length, drainage area, and number of individual streams for each stream order in the river network based on the stream-order area $\left(\mathrm{R}_{\mathrm{a}}\right)$, number $\left(\mathrm{R}_{\mathrm{b}}\right)$, and length $\left(R_{L}\right)$ ratios developed by Horton (1945). The empirical values of these ratios for the Río Mameyes network are $3.5,3.3$, and 1.7, respectively, and were obtained from a digital topological river network developed from a 10-m digital elevation model. We estimated mean river width and depth for each stream order from hydraulic scaling relationships (Leopold and Maddock 1953) based on downstream scaling exponents and coefficients developed specifically for the Río Mameyes network (Pike et al. 2010). Direct drainage from land to each river order was estimated based on the proportion of total river-network length represented by that river order, assuming that inputs enter the upstream end of a stream reach, as described by Wollheim et al. (2006).

In our model, we assumed that $\mathrm{NH}_{4}{ }^{+}$and $\mathrm{NO}_{3}{ }^{-}$in streams of a given order are sourced from: 1) local groundwater inputs and 2) upstream river reaches. $\mathrm{N}$ input from the catchment $\left(N_{L O A D}, \mathrm{mg} / \mathrm{d}\right)$ into each stream order $i$ is calculated as:

$$
N_{L O A D_{i}}=R O \times D_{i} \times N_{G W}
$$

$R O$ is the median daily runoff $(4.9 \mathrm{~mm} / \mathrm{d}$; USGS 50065500 , 38-y period of record), $D_{i}$ is the watershed area that drains directly into each stream order, and $N_{G W}$ is the concentration of dissolved $\mathrm{NH}_{4}{ }^{+}$or $\mathrm{NO}_{3}{ }^{-}$in groundwater. We assigned $N_{G W}$ as $0.14 \mathrm{mg} \mathrm{NH}_{4}{ }^{+}-\mathrm{N} / \mathrm{L}$ and $0.10 \mathrm{mg} \mathrm{NO}_{3}{ }^{-}-\mathrm{N} /$ $\mathrm{L}$, respectively, based on the average concentration from soil lysimeters and shallow groundwater wells within the Río Mameyes and the neighboring Río Sonadora watersheds (McDowell et al. 1992, 1996, McDowell 1998, McDowell and Liptzin 2014, Cusack et al. 2016). In applying Eq. 8, we assumed spatially uniform runoff and $N_{L O A D}$ to isolate the hydrological and biological processes that affect the distribution of nutrient removal throughout the river network.

A proportion of $\mathrm{N}$ inputs to an individual stream of order $i$ is removed by in-stream processing ( $R_{i}$, unitless) associated with benthic sediments:

$$
R_{i}=1-e^{\left(-v_{f} / H L_{i}\right)} .
$$

$v_{\mathrm{f}}$ represents either the net $\mathrm{NH}_{4}{ }^{+} v_{\mathrm{f}}$ (mean; our study) or the net $\mathrm{NO}_{3}{ }^{-} v_{\mathrm{f}}(0.41 \mathrm{~mm} / \mathrm{min}$; mean, $n=9$ streams; Potter et al. 2010), respectively. $H L$ is the hydraulic load, equivalent to mean discharge over streambed area $(Q / w l)$ for each stream order $i$ of mean width $w$ and length $l$. We conservatively assumed that neither $\mathrm{NH}_{4}{ }^{+} v_{\mathrm{f}}$ nor $\mathrm{NO}_{3}{ }^{-} v_{\mathrm{f}}$ vary with stream size because: 1 ) the mean $v_{\mathrm{f}}$ encompasses the observed range, which was not strongly related to most of the covariates we considered (see Results below) and 2) across streams, syntheses of empirical measurements of nutrient uptake pro- vide little evidence that $v_{\mathrm{f}}$ changes systematically with stream size (Ensign and Doyle 2006, Tank et al. 2008, Hall et al. 2013). We also assumed that a uniform fraction of immobilized $\mathrm{NH}_{4}{ }^{+}$is converted to $\mathrm{NO}_{3}{ }^{-}$via nitrification (mean; our study), and any $\mathrm{N}$ in excess of benthic demand is delivered downstream to larger stream reaches. We tested the sensitivity of model results to these assumptions, especially variability in $\mathrm{NH}_{4}{ }^{+} v_{\mathrm{f}}, \mathrm{NO}_{3}{ }^{-} v_{\mathrm{f}}$, and nitrification by: 1) testing all combinations of parameter values representing the observed mean $\pm 1 \mathrm{SE}$ for $\mathrm{NH}_{4}{ }^{+} v_{\mathrm{f}}, \mathrm{NO}_{3}{ }^{-} v_{\mathrm{f}}$, and $\% \mathrm{NH}_{4}{ }^{+}$nitrified, and 2) testing a model scenario where $\mathrm{NH}_{4}{ }^{+}$and $\mathrm{NO}_{3}{ }^{-} v_{\mathrm{f}}$ increased by $20 \%$ with each stream order from the mean $v_{\mathrm{f}}$ rates described above to simulate increasing $\mathrm{N}$ demand with stream size, as might be expected with downstream opening of the canopy and increased assimilative $\mathrm{N}$ demand (Tank et al. 2008).

This modeling exercise necessarily simplifies real systems and is not meant to predict or forecast $\mathrm{N}$ exports from the Río Mameyes watershed. Rather, we used this heuristic mass-balance approach to ask: what are the implications of observed rates of $\mathrm{NH}_{4}{ }^{+}$uptake and nitrification when applied to an entire river network? In this way, our empirical observations of stream $\mathrm{NH}_{4}{ }^{+}$uptake and nitrification enabled us to assess the potential for these tropical streams to alter the amount and form of $\mathrm{N}$ that is exported from the river network.

\section{RESULTS}

Physicochemical characteristics and stream metabolism

Mean transient storage residence time $\left(T_{s}\right)$ was short and ranged from $<0.5$ to $16 \mathrm{~min}$. Background $\mathrm{NH}_{4}{ }^{+}$concentrations were consistently below analytical detection, although $\mathrm{NO}_{3}{ }^{-}$concentrations were relatively high for an undisturbed watershed (57-161 $\mu \mathrm{g} \mathrm{N} / \mathrm{L})$. Background DOC concentrations were low, ranging from 0.5 to $1.7 \mathrm{mg} \mathrm{C} / \mathrm{L}$, and DOC : DIN molar ratios varied from 3.4 to 16.6. Daily average light intensity ranged from 2.0 to $66.6 \mu \mathrm{E} \mathrm{m}^{-2} \mathrm{~s}^{-1}$ (Table 2), but was not significantly related to GPP over the observed ranges in our study $(r=-0.25, p=0.413)$. Chl $a$ standing stock ranged from 0.7 to $24.9 \mathrm{mg} / \mathrm{m}^{2}$. $\log _{\mathrm{e}}(\mathrm{Chl} a)$ was not significantly correlated with stream GPP $(r=-0.01$, $p=0.982$ ), but Chl $a$ was greatest at Caimitillo, the stream site with the highest daily average light intensity (Table 2).

\section{$\mathrm{NH}_{4}{ }^{+}$uptake across streams}

In each of our $14 \mathrm{NH}_{4}{ }^{+}$enrichment experiments, we observed significant hysteresis in the relationship between $U_{\text {net }}$ and reach-averaged $\mathrm{NH}_{4}{ }^{+}$concentration. $\mathrm{NH}_{4}{ }^{+} U_{\text {net }}$ was consistently greater for samples on the rising limb than on the falling limb of the breakthrough curve, as shown for an experiment conducted in the Angelito stream (Fig. 2). Our estimates of $v_{\mathrm{f}}$ from the advection-dispersion transport model 
corroborate these patterns because net stream $\mathrm{NH}_{4}{ }^{+} v_{\mathrm{f}}$ was much greater than net $\mathrm{NH}_{4}{ }^{+} v_{\mathrm{f}}$ in transient storage zones, which was undetectable (i.e., not different from 0 ) for most of our experiments (Table 2).

Mass removal of added $\mathrm{NH}_{4}{ }^{+}$ranged from 25 to $80 \%$ in our 14 experiments (data not shown), and net stream $\mathrm{NH}_{4}{ }^{+} v_{\mathrm{f}}$ ranged from 0.3 to $8.5 \mathrm{~mm} / \mathrm{min}$ (mean $=2.7 \mathrm{~mm} / \mathrm{min}$; Table 2). Variability in $\mathrm{NH}_{4}{ }^{+} v_{\mathrm{f}}$ was greater among streams (coefficient of variation $[\mathrm{CV}]=71 \%$ ) than within intensive study streams with $>2$ measurements (Bisley $1 \mathrm{CV}=42 \%$; Bisley $3 \mathrm{CV}=24 \%)$. Net stream $\mathrm{NH}_{4}{ }^{+} v_{\mathrm{f}}$ was not significantly correlated with most physical, chemical, and biological covariates that we considered (Fig. 3A-I, Table 3) with the exception of a positive correlation between net stream $\mathrm{NH}_{4}{ }^{+} v_{\mathrm{f}}$ and Chl $a$ (Fig. 3B, Table 3), suggesting that stream $\mathrm{NH}_{4}{ }^{+}$demand increases with autotrophic biomass.

\section{Nitrification}

On average, $49 \%$ of added $\mathrm{NH}_{4}{ }^{+}$was converted to $\mathrm{NO}_{3}{ }^{-}$, which suggests that nitrification was a significant fate of added $\mathrm{NH}_{4}{ }^{+}$. Across all experiments, 14 to $78 \%$ of added $\mathrm{NH}_{4}{ }^{+}$was nitrified immediately (Table 2), resulting in nitrification rates ranging from 0.2 to $16.9 \mu \mathrm{g} \mathrm{N} \mathrm{m}^{-2} \mathrm{~min}^{-1}$. Percent $\mathrm{NH}_{4}{ }^{+}$nitrified was not significantly correlated with net stream $\mathrm{NH}_{4}{ }^{+} v_{\mathrm{f}}$, background concentrations of dissolved $\mathrm{N}$ and $\mathrm{C}$, or daily average light intensity over their observed range of variability (Table 3 ). Percent $\mathrm{NH}_{4}{ }^{+}$nitrified varied
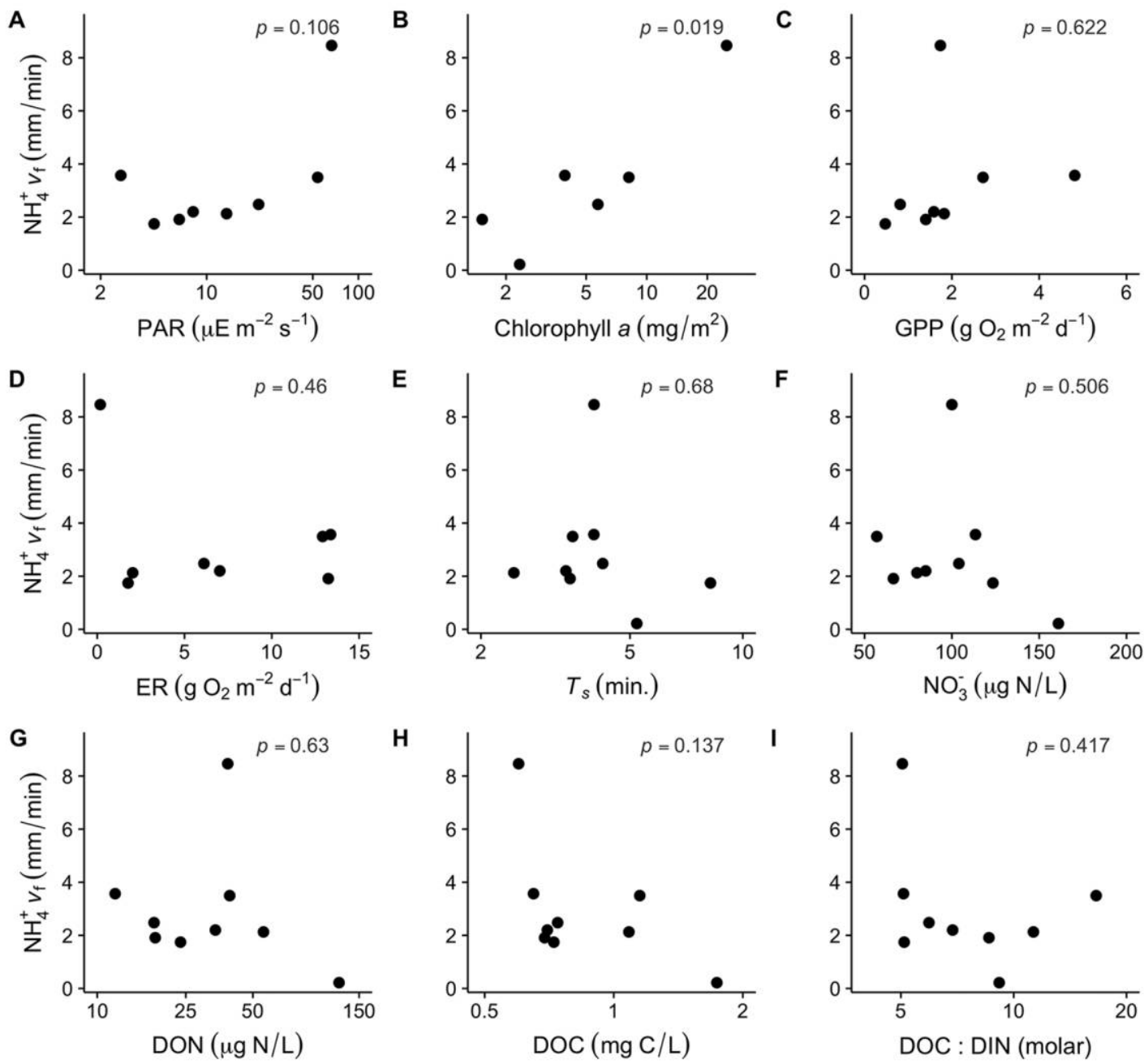

Figure 3. Scatterplots showing the correlations between net stream $\mathrm{NH}_{4}{ }^{+}$uptake velocity $\left(v_{\mathrm{f}}\right)$ and photosynthetically active radiation (PAR) (A), algal biomass standing stock (chlorophyll $a$ ) (B), gross primary production (GPP) (C), ecosystem respiration (ER) (D), transient storage zone residence time $\left(T_{s}\right)(\mathrm{E}), \mathrm{NO}_{3}{ }^{-}(\mathrm{F})$, dissolved organic $\mathrm{N}(\mathrm{DON})(\mathrm{G})$, dissolved organic $\mathrm{C}(\mathrm{DOC})(\mathrm{H})$, and the DOC:dissolved inorganic $\mathrm{N}$ (DIN) molar ratio (I). If experiments were performed in multiple reaches within a stream on the same day, we used mean values of covariates and net stream $v_{\mathrm{f}}$ (resulting in $n=9$ ), although sample size for individual bivariate relationships varied depending on data availability (Table 3). 
Table 3. Pearson correlation coefficients for the relationships between net stream channel $\mathrm{NH}_{4}{ }^{+}$uptake velocity $\left(v_{\mathrm{f}}\right)$ and $\% \mathrm{NH}_{4}{ }^{+}$nitrified vs physical, chemical, and biological covariates. Photosynthetically active radiation (PAR), chlorophyll $a$, transient storage residence time $\left(T_{s}\right)$, ambient dissolved organic C (DOC), ambient dissolved organic $\mathrm{N}(\mathrm{DON})$, and DOC:dissolved inorganic $\mathrm{N}$ (DIN) molar ratio were $\ln (x$-transformed) to meet normality assumptions. Stream metabolism was not measured at the Máquina site, and chlorophyll $a$ was not measured during the January/early February experiments at Bisley 1, Bisley 3, and Angelito. Bold indicates $(p<0.05)$.

\begin{tabular}{|c|c|c|c|c|c|}
\hline \multirow[b]{2}{*}{ Predictor variables } & \multirow[b]{2}{*}{$n$} & \multicolumn{2}{|c|}{ Net stream $\mathrm{NH}_{4}^{+} v_{\mathrm{f}}$} & \multicolumn{2}{|c|}{$\% \mathrm{NH}_{4}{ }^{+}$nitrified } \\
\hline & & $p$ & $r$ & $p$ & $r$ \\
\hline $\operatorname{PAR}\left(\mu \mathrm{E} \mathrm{m}^{-2} \mathrm{~s}^{-1}\right)$ & 8 & 0.106 & 0.61 & 0.346 & 0.39 \\
\hline Chlorophyll $a\left(\mathrm{mg} / \mathrm{m}^{2}\right)$ & 6 & 0.019 & 0.89 & 0.838 & 0.11 \\
\hline $\operatorname{GPP}\left(\mathrm{g} \mathrm{O}_{2} \mathrm{~m}^{-2} \mathrm{~d}^{-1}\right)$ & 8 & 0.622 & 0.21 & 0.091 & 0.64 \\
\hline $\mathrm{ER}\left(\mathrm{g} \mathrm{O}_{2} \mathrm{~m}^{-2} \mathrm{~d}^{-1}\right)$ & 8 & 0.460 & -0.31 & 0.300 & 0.42 \\
\hline$T_{s}(\min )$ & 9 & 0.680 & -0.16 & 0.128 & -0.55 \\
\hline Ambient $\mathrm{NO}_{3}{ }^{-}(\mu \mathrm{g} \mathrm{N} / \mathrm{L})$ & 9 & 0.506 & -0.26 & 0.573 & -0.22 \\
\hline Ambient DON ( $\mu \mathrm{g} \mathrm{N} / \mathrm{L})$ & 9 & 0.630 & -0.19 & 0.577 & 0.22 \\
\hline Ambient DOC (mg C/L) & 9 & 0.137 & -0.54 & 0.416 & 0.31 \\
\hline DOC:DIN molar ratio & 9 & 0.417 & -0.31 & 0.198 & 0.47 \\
\hline
\end{tabular}

within intensive study streams (Bisley $1 \mathrm{CV}=76 \%$, Bisley 3 $\mathrm{CV}=46 \%$ ), but we are unable to explain this variation at the individual stream or landscape levels with our data.

\section{River-network $\mathbf{N}$ dynamics and export}

Based on stream hydrography and hydraulic measurements throughout the upper Río Mameyes network, stream length and benthic surface area were skewed toward the headwaters. Total stream length for $1^{\text {st }}$ - to $5^{\text {th }}$-order streams was $45,23,12,6$, and $3 \mathrm{~km}$, and total benthic surface area was $0.041,0.033,0.026,0.021$, and $0.017 \mathrm{~km}^{2}$, respectively. Direct inputs to the river network were distributed more heavily toward $1^{\text {st }}$ - and $2^{\text {nd }}$-order streams, which together receive $76 \%$ of the direct drainage from land. Network-scale $\mathrm{NH}_{4}{ }^{+}$uptake declined from $6 \mathrm{~kg} \mathrm{~N} / \mathrm{d}$ integrated across all $1^{\text {st }}$-order streams to $0.6 \mathrm{~kg} \mathrm{~N} / \mathrm{d}$ in the $5^{\text {th }}$-order mainstem river (Fig. 4A). This decline in $\mathrm{NH}_{4}{ }^{+}$uptake with stream order occurs because: 1) most $\mathrm{NH}_{4}{ }^{+}$delivered to the river network enters small streams first, and 2) biological demand for $\mathrm{NH}_{4}{ }^{+}$is relatively high compared to the length and residence time of small streams (Fig. 4B), resulting in rapid removal near the point where $\mathrm{NH}_{4}{ }^{+}$enters the network. Proportional removal of $\mathrm{NH}_{4}{ }^{+}$inputs to a stream of a given order declined from 0.90 for $1^{\text {st }}$-order streams to 0.52 in the $5^{\text {th }}$-order mainstem river (Fig. 4B).

Network-scale $\mathrm{NO}_{3}{ }^{-}$uptake also declined with stream size from $2.3 \mathrm{~kg} \mathrm{~N} / \mathrm{d}$ (integrated across all $1^{\text {st }}$-order streams) to $0.9 \mathrm{~kg} \mathrm{~N} / \mathrm{d}$ in the $5^{\text {th }}$-order mainstem (Fig. 4A). $\mathrm{NO}_{3}{ }^{-}$uptake was more important than $\mathrm{NH}_{4}{ }^{+}$uptake in the largest stream orders. Similar to $\mathrm{NH}_{4}{ }^{+}$, the pattern in $\mathrm{NO}_{3}{ }^{-}$uptake at the network scale results from the combined influence of biotic demand and the distribution of $\mathrm{NO}_{3}{ }^{-}$inputs from the catchment, although $\mathrm{NO}_{3}{ }^{-}$uptake is also influenced by in- stream inputs from nitrification. Nitrification followed a pattern similar to that of direct $\mathrm{NH}_{4}{ }^{+}$inputs and uptake and declined with stream order (equal to 3.0, 1.7, 0.9, 0.5, and $0.3 \mathrm{~kg} \mathrm{~N} / \mathrm{d}$ in $1^{\text {st }}$ - to $5^{\text {th }}$-order streams, respectively). Therefore, downstream $\mathrm{NO}_{3}{ }^{-}$uptake was fueled by upstream nitrification. Proportional removal of $\mathrm{NO}_{3}{ }^{-}$inputs to a stream of a given order declined from 0.30 for $1^{\text {st }}$-order streams to 0.11 in the $5^{\text {th }}$-order mainstem (Fig. 4B). For inputs to a given stream order, proportional $\mathrm{N}$ removal was lower for $\mathrm{NO}_{3}{ }^{-}$than $\mathrm{NH}_{4}{ }^{+}$because of the low $\mathrm{NO}_{3}{ }^{-} v_{\mathrm{f}}$ relative to $\mathrm{NH}_{4}{ }^{+} v_{\mathrm{f}}$ (Ensign and Doyle 2006). Total inputs of $\mathrm{NH}_{4}{ }^{+}$and $\mathrm{NO}_{3}{ }^{-}$to the river network were similar (13.4 and $15.9 \mathrm{~kg} \mathrm{~N} / \mathrm{d}$, respectively, with $6.3 \mathrm{~kg} \mathrm{~N} / \mathrm{d}$ of $\mathrm{NO}_{3}{ }^{-}$inputs from in-stream nitrification), but differences in biotic demand resulted in lower estimated $\mathrm{NH}_{4}{ }^{+}$export $(0.5 \mathrm{~kg}$ $\mathrm{N} / \mathrm{d})$ than $\mathrm{NO}_{3}{ }^{-}$export $(7.5 \mathrm{~kg} \mathrm{~N} / \mathrm{d})$. At the network scale, model results indicated that $2.9 \mathrm{~kg} \mathrm{~N} / \mathrm{d}$ of the total $\mathrm{NO}_{3}{ }^{-}$ export was produced within the river network by nitrification.

The proportion of $\mathrm{N}$ inputs removed within individual streams, and therefore, the magnitude of network-scale $\mathrm{NH}_{4}{ }^{+}$and $\mathrm{NO}_{3}{ }^{-}$uptake were only slightly sensitive to the parameter values for $\mathrm{NH}_{4}{ }^{+} v_{\mathrm{f}}, \mathrm{NO}_{3}{ }^{-} v_{\mathrm{f}}$, and $\% \mathrm{NH}_{4}{ }^{+}$nitrified, based on ranges in field measurements (Fig. 4A, B). Small streams were relatively more important than larger streams for $\mathrm{N}$ uptake in the Río Mameyes network across all parameter combinations (Fig. 4A, B) regardless of our a priori assumption of constant $v_{\mathrm{f}}$ with stream size (Fig. S1A, B vs Fig. 4A, B). Network-scale $\mathrm{NH}_{4}{ }^{+}$uptake was relatively unchanged despite increasing $\mathrm{NH}_{4}{ }^{+} v_{\mathrm{f}}$ with stream order $(<7 \%$ increase in $\mathrm{NH}_{4}{ }^{+}$uptake for each stream order; Fig. S1A) because $\mathrm{NH}_{4}{ }^{+}$demand in small streams (based on measured $v_{\mathrm{f}}$ ) is high enough to limit downstream transport of $\mathrm{NH}_{4}{ }^{+}$to larger streams. Increased $\mathrm{NO}_{3}{ }^{-} v_{\mathrm{f}}$ with stream size 

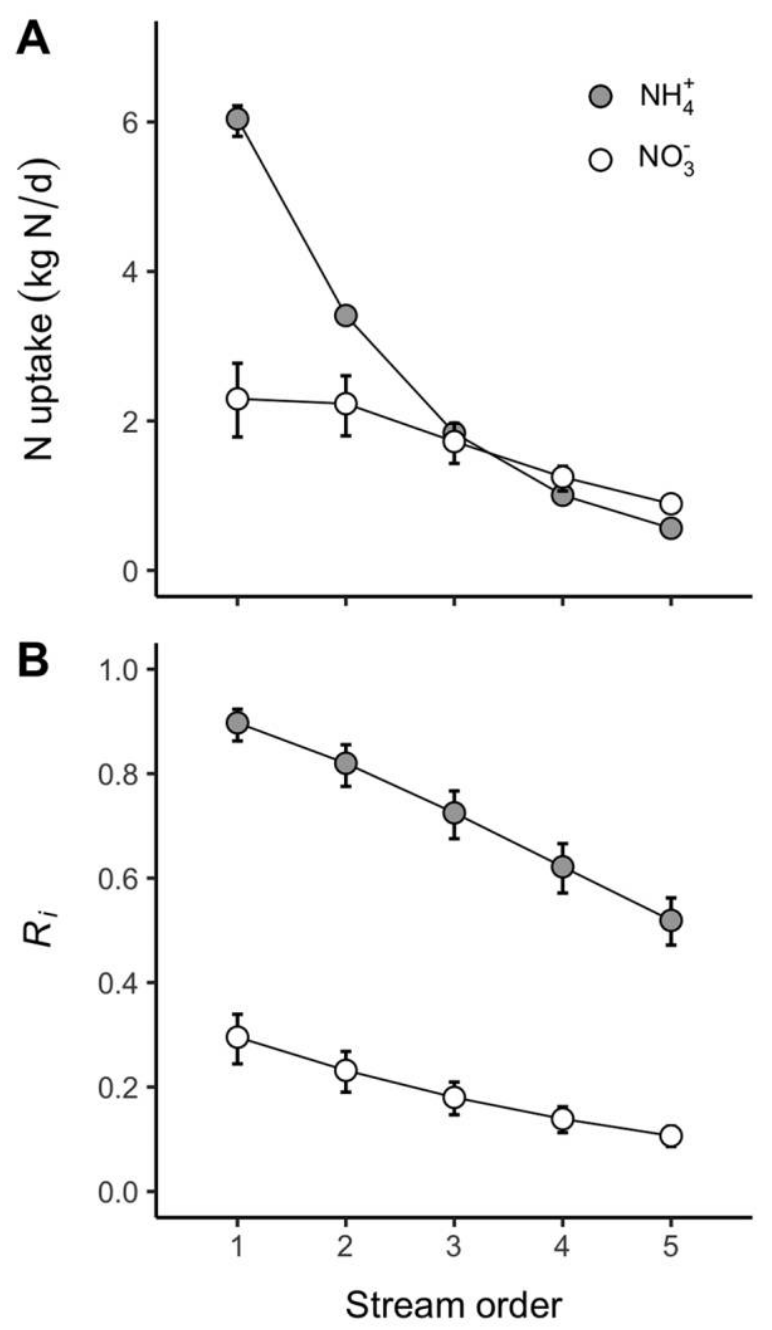

Figure 4. Mean $( \pm \mathrm{SE})$ network-scale $\mathrm{N}$ uptake $(\mathrm{A})$ and reach-scale proportional removal of $\mathrm{NH}_{4}{ }^{+}$and $\mathrm{NO}_{3}{ }^{-}$inputs $\left(R_{i}\right)(\mathrm{B})$ in relation to stream order. Error bars represent results from model-sensitivity analyses where parameter values were equal to mean $\pm 1 \mathrm{SE}$ of observed $\mathrm{NH}_{4}{ }^{+} v_{\mathrm{f}}, \mathrm{NO}_{3}{ }^{-} v_{\mathrm{f}}$, and \% $\mathrm{NH}_{4}{ }^{+}$nitrified.

did result in slightly higher network-scale $\mathrm{NO}_{3}{ }^{-}$uptake rates compared to the base model scenario (e.g., $\mathrm{NO}_{3}{ }^{-}$uptake increased by $18 \%$ across $1^{\text {st }}$-order streams and increased by $62 \%$ in the $5^{\text {th }}$-order mainstem). However, $\mathrm{NO}_{3}{ }^{-}$uptake in this increasing $\mathrm{NO}_{3}{ }^{-} v_{\mathrm{f}}$ scenario was greatest in $2^{\text {nd }}$-order streams, and small streams remained the more important sites of $\mathrm{NO}_{3}{ }^{-}$removal at the network scale (Fig. S1A).

\section{DISCUSSION}

$\mathrm{NH}_{4}{ }^{+}$uptake rates are high in the mountainous tropical streams we studied. $\mathrm{NH}_{4}{ }^{+} v_{\mathrm{f}}$ was consistently greater than $\mathrm{NO}_{3}{ }^{-} v_{\mathrm{f}}$ previously measured in 9 streams spanning a range of human land uses in Puerto Rico (Potter et al. 2010). Our habitat-partitioned estimates of $\mathrm{NH}_{4}{ }^{+} v_{\mathrm{f}}$ suggest that the stream channel is very reactive compared to transient stor- age zones, possibly because of the influence of autotrophic production and assimilatory uptake on stream $\mathrm{NH}_{4}{ }^{+}$dynamics. Nitrification represented a large proportion of $\mathrm{NH}_{4}{ }^{+}$uptake, and when reach-scale $\mathrm{N}$ uptake and transformation rates were considered at the river-network scale, we estimated that $39 \%$ of modeled watershed $\mathrm{NO}_{3}{ }^{-}$export comes from nitrification within the river network itself. Model results indicated that small streams were relatively more important than large streams for $\mathrm{NH}_{4}{ }^{+}$and $\mathrm{NO}_{3}{ }^{-}$removal because of the distribution of catchment $\mathrm{N}$ inputs and downstream hydraulic geometry. Taken together, these results suggest that streams and rivers can significantly transform catchment $\mathrm{N}$ loads, but that the spatial distribution of $\mathrm{N}$ removal depends on river network geomorphology and biological $\mathrm{N}$ demand.

\section{$\mathrm{NH}_{4}{ }^{+}$uptake}

$\mathrm{NH}_{4}{ }^{+} v_{\mathrm{f}}$ spanned a range commonly observed in streams (Hall et al. 2002, Ensign and Doyle 2006). However, despite differences in watershed topography and geology (Table 1) as well as stream chemistry and hydrology (Table 2), $\mathrm{NH}_{4}{ }^{+} v_{\mathrm{f}}$ was relatively uniform across streams, and the variability was driven largely by 1 stream with a disproportionately high $\mathrm{NH}_{4}{ }^{+} v_{\mathrm{f}}$ (Caimitillo). Stream metabolism should influence $\mathrm{NH}_{4}{ }^{+}$uptake (Wollheim et al. 2001, Hall and Tank 2003, Newbold et al. 2006, Hoellein et al. 2007). However, $\mathrm{NH}_{4}{ }^{+} v_{\mathrm{f}}$ was positively correlated with $\mathrm{Chl} a$ standing stock but not GPP (Fig. 3B, C). This result could be a consequence of the offset between metabolism and nutrient uptake in some streams because, despite similar weather conditions between measurements, other factors including turbidity or time since scour can affect daily variation in GPP (Uehlinger 2000). Our observation that benthic $\mathrm{Chl} a$ was related to $\mathrm{NH}_{4}{ }^{+}$uptake is consistent with high rates of epilithon uptake of isotopically labeled $\mathrm{NH}_{4}{ }^{+}$in the Bisley 3 stream (Merriam et al. 2002), suggesting that algae in biofilms can contribute to inorganic $\mathrm{N}$ uptake even in relatively shaded streams. Similar to previous findings in temperate streams, we did not observe a strong influence of ER on $\mathrm{NH}_{4}{ }^{+}$uptake (Webster et al. 2003, Fellows et al. 2006). In these tropical streams, leaf litter is decomposed rapidly (Heartsill-Scalley et al. 2012), so microbial heterotroph $\mathrm{N}$ demand might be satisfied by recycling high-energy organic $\mathrm{N}$ during decomposition (Sinsabaugh and Follstad-Shah 2012) rather than by using inorganic $\mathrm{N}$ from the water column. Our measurements were limited to small streams, and the variability in light intensity, GPP, and ER across our sites probably underestimates the variability that might be observed at the scale of a larger river network. Further measurements in larger rivers may help statistically examine the influence of metabolism on $\mathrm{NH}_{4}{ }^{+}$uptake.

$\mathrm{NH}_{4}{ }^{+}$uptake represents the net balance between multiple processes that consume and produce $\mathrm{NH}_{4}{ }^{+}$and integrates multiple habitats within a stream reach. We observed 
clockwise hysteresis patterns in $U_{n e t}$ during each of our experiments. This observation suggests that: 1) hydrologic exchange with transient storage is significant, and 2) $K_{t}$ differs between the main channel and transient storage zones (e.g., subsurface hyporheic flow and surface pools). One explanation for the clockwise hysteresis pattern is preferential uptake in the stream channel combined with downstream flowpaths through less-reactive hyporheic zones. Alternatively, calculations of sample-specific uptake rates (sensu Covino et al. 2010) are sensitive to abiotic sorption of $\mathrm{NH}_{4}{ }^{+}$to sediments. Concentration-driven changes in net adsorption could result in $\mathrm{NH}_{4}{ }^{+}$sorption (and overestimation of $\mathrm{NH}_{4}{ }^{+}$ removal) on the rising limb of the breakthrough curve followed by desorption (and underestimation of $\mathrm{NH}_{4}{ }^{+}$removal) on the falling limb as sediment-water concentration gradients shift with $\mathrm{NH}_{4}{ }^{+}$concentration in the water column. We observed increasing $\mathrm{NH}_{4}{ }^{+}: \mathrm{Cl}$ ratios on the falling limb of the breakthrough curve in 4 of our experiments, as would be expected given desorption of added $\mathrm{NH}_{4}{ }^{+}$(Day and Hall 2017). However, we did not observe this pattern in most experiments with clockwise hysteresis in $U_{n e t}$, so we assume that the adsorption effect was limited across streams. Hysteresis patterns have been observed by numerous investigators conducting pulse nutrient-enrichment experiments (Gibson et al. 2015, Trentman et al. 2015) and may provide useful information about habitat-specific uptake rates in streams, although abiotic adsorption to sediments must be considered as well.

\section{Nitrification}

Nitrification was an important mechanism of $\mathrm{NH}_{4}{ }^{+}$removal during downstream transport. Our observation that on average, $49 \%$ of added $\mathrm{NH}_{4}{ }^{+}$was converted to $\mathrm{NO}_{3}{ }^{-}$is consistent with previous work in Bisley 3, where Merriam et al. (2002) found that nitrification accounted for $57 \%$ of total $\mathrm{NH}_{4}{ }^{+}$uptake during a 6 -wk ${ }^{15} \mathrm{NH}_{4}{ }^{+}$tracer experiment. In streams across the USA, Peterson et al. (2001) found that on average, 20 to $30 \%$ of $\mathrm{NH}_{4}{ }^{+}$uptake was nitrified, which, taken together with our findings, indicates that nitrification can rival assimilation as a short-term sink for dissolved $\mathrm{NH}_{4}{ }^{+}$. Our study confirms the generality of high nitrification rates in mountainous tropical streams, where microbes are probably energy-limited because decomposition of terrestrial leaf litter is rapid (Heartsill-Scalley et al. 2012), dissolved organic $\mathrm{C}$ is strongly retained by mineral soils (McDowell 1998, Neff and Asner 2001), and light availability limits primary production (Ortiz-Zayas et al. 2002, Tank and Dodds 2003). However, our observations of nitrification as a percentage of $\mathrm{NH}_{4}{ }^{+}$uptake (14-78\%) span a larger range than was observed for 12 streams representing diverse biomes throughout the USA (Peterson et al. 2001). Much of the variation in our study occurred within the same stream, suggesting that nitrification rates in streams can vary temporally as much as spatially. In Bisley 1 , for example, nitrifi- cation varied from $18 \%$ of $\mathrm{NH}_{4}{ }^{+}$uptake in late January to $78 \%$ when measured again in early March. This pattern was repeated in the 4 stream reaches in which we performed multiple $\mathrm{NH}_{4}{ }^{+}$enrichment experiments over a 6-wk period, suggesting that conditions were more favorable for nitrification later in the spring. We cannot explain the temporal variability in net nitrification with our data, although we speculate that leaf litter and particulate organic $\mathrm{C}$ standing stocks may have become depleted during the late winter when litterfall rates are lowest (Silver et al. 2014).

Percent $\mathrm{NH}_{4}{ }^{+}$nitrified did not increase with background inorganic $\mathrm{N}$ concentration, as has been previously observed in temperate streams (Bernhardt et al. 2002, Newbold et al. 2006). Nitrifiers are thought to be poor competitors for $\mathrm{NH}_{4}{ }^{+}$relative to heterotrophic bacteria and autotrophs, and Bernhardt et al. (2002) hypothesized that higher levels of inorganic $\mathrm{N}$ may alleviate heterotrophic demand and allow nitrifiers to use available $\mathrm{NH}_{4}{ }^{+}$. However, streams draining tropical forests in general, and the Luquillo Mountains specifically, have high dissolved inorganic N concentrations relative to forested streams in temperate biomes (Lewis et al. 1999, Brookshire et al. 2012), and nitrifiers may not be in competition with heterotrophs for $\mathrm{NH}_{4}{ }^{+}$. We also found no relationship between nitrification rates and DOC concentration despite the expectation that low $\mathrm{C}$ availability favors nitrifiers over heterotrophic microbes that rely on organic $\mathrm{C}$ as an energy source (Strauss and Lamberti 2000, Helton et al. 2015). High inorganic $\mathrm{N}$ and low DOC availability may favor nitrification in tropical mountainous streams in general, but other factors, such as microbial community composition, litterfall, or variable redox state and hydrologic connectivity of groundwater flowpaths likely regulate stream nitrification rates.

\section{River-network $\mathrm{N}$ dynamics and export}

High nitrification potential in streams of the Luquillo Mountains suggests that a significant amount of $\mathrm{NO}_{3}{ }^{-}$may be produced in tropical streams themselves. At the rivernetwork scale, model results indicate that $39 \%$ of watershed $\mathrm{NO}_{3}{ }^{-}$export is produced in streams and rivers, challenging the idea that streamwater $\mathrm{NO}_{3}{ }^{-}$provides an integrated signal of plant-soil biogeochemical processes (Brookshire et al. 2012). $\mathrm{NH}_{4}{ }^{+}$uptake and nitrification in streams transforms the catchment $\mathrm{N}$ load into $\mathrm{NO}_{3}{ }^{-}$, which is less likely to be consumed during the short transit times from land to ocean. Thus, in-stream nitrification results in "shunting" (sensu Raymond et al. 2016) of N to the coastal zone.

Small streams removed a greater proportion of $\mathrm{N}$ inputs than large streams in the Río Mameyes network. The importance of small streams for regulating watershed nutrient export has been well documented (Alexander et al. 2000, Peterson et al. 2001), although recent research has highlighted an increased role for large rivers as important sites of nutrient removal (Seitzinger et al. 2002, Ensign and 
Doyle 2006, Wollheim et al. 2006, Hall et al. 2013). These conclusions appear contradictory, but the role of small vs large streams in river-network nutrient removal is not mutually exclusive, and the patterns in the Río Mameyes network are governed by the distribution of nutrient inputs, nutrient-removal efficiency, and river-network morphology.

Direct $\mathrm{N}$ inputs from land are distributed toward headwater streams in the Río Mameyes network, so high $\mathrm{NH}_{4}{ }^{+}$ uptake efficiency in small streams means that little $\mathrm{NH}_{4}{ }^{+}$ is transported downstream, producing a steep negative relationship between $\mathrm{NH}_{4}{ }^{+}$uptake and stream size (Fig. 4A). Therefore, despite our a priori assumption of constant $\mathrm{NH}_{4}{ }^{+} v_{\mathrm{f}}$ with stream size, $\mathrm{NH}_{4}{ }^{+}$removal in larger streams is limited by $\mathrm{NH}_{4}{ }^{+}$availability. Larger streams remained relatively more important for $\mathrm{NO}_{3}{ }^{-}$uptake because low $\mathrm{NO}_{3}{ }^{-} v_{\mathrm{f}}$ and in-stream nitrification allow $\mathrm{NO}_{3}{ }^{-}$transport to downstream reaches. $\mathrm{NO}_{3}{ }^{-}$uptake in larger streams also would increase if $\mathrm{NO}_{3}{ }^{-} v_{\mathrm{f}}$ were to increase with stream size (e.g., with downstream opening of the canopy and increased assimilative $\mathrm{N}$ demand in downstream reaches) (Fig. S1A). Because uptake velocities typically differ considerably for $\mathrm{NH}_{4}{ }^{+}$and $\mathrm{NO}_{3}{ }^{-}$(Ensign and Doyle 2006), the roles of small vs large rivers in regulating watershed exports also shift with the strength of biotic demand (Wollheim et al. 2006).

Geomorphology is also a large driver of nutrient removal in river networks. Wollheim et al. (2006) found that the proportion of $\mathrm{NO}_{3}{ }^{-}$removal as a function of stream size was sensitive to channel-width scaling and shifted from smallto large-stream dominance when the hydraulic width exponent increased from 0.36 to 0.52 . In the Río Mameyes network, headwater streams are relatively wide, and width increases slowly in the downstream direction (hydraulic width exponent $=0.35$ ), probably because of high stormflows and steep slopes that shape channel geometry (Pike et al. 2010). As a result of the slow increases in channel width in the Río Mameyes, the hydraulic load increases rapidly with increasing stream size, limiting the contact with reactive benthic sediments compared to smaller streams (Seitzinger et al. 2002).

The relationship between nutrient removal and river size varies depending on the distribution of nutrient inputs, biological uptake rates, and hydraulic loads. The latter is also influenced by daily runoff rates, the distribution of stream length, and the downstream scaling of channel width (Ensign and Doyle 2006, Mulholland et al. 2008). Therefore, patterns in the spatial distribution of aquatic nutrient removal would be expected to differ in river networks with similar $\mathrm{N}$ uptake rates but different geomorphology, and our results highlight the need for further research comparing nutrient spiraling in river networks with varying hydrologic and geomorphic characteristics. The modeling exercise that we presented here represents steady-state conditions and considers only a snapshot in time during base flow. We expect that high-flow events would decrease the pro- portion of $\mathrm{NH}_{4}{ }^{+}$removed by headwater streams, allowing a greater role of larger rivers in network $\mathrm{N}$ uptake (Wollheim et al. 2008a, Raymond et al. 2016). Further empirical work quantifying $\mathrm{N}$ uptake and nitrification under different flow conditions and in larger rivers would help refine these expectations, but our approach is an important step toward understanding nutrient spiraling in a tropical river network. We suggest that systematic study of biogeochemical cycling throughout river networks will help bridge the gap between our understanding of site-level processes and large-scale biogeochemical patterns.

\section{ACKNOWLEDGEMENTS}

Author contributions: LEK performed the research, analyzed the data, and wrote the paper. CS contributed new methods and analyzed the data. WMW, JR, and WHM performed the research. All authors discussed the results and contributed to development of the manuscript.

We thank Geoffrey Schwaner, Jonathan Torruellas, Jody Potter, Ford Ballantyne, Ken Sheehan, and Christina Baker for invaluable field assistance, and Miguel Leon and Michelle Shattuck for providing their expertise with the Luquillo Critical Zone Observatory spatial data sets. Two anonymous referees provided helpful comments and insights on earlier drafts of this manuscript. This research was supported by the National Science Foundation (NSF) as part of the Scaling Consumers and Lotic Ecosystem Rates (SCALER) project (EF1065255). Additional support for LEK was provided by an NSF graduate research fellowship (GRFP-0913620) and the Mulholland Award for Biogeochemical Research from the Society for Freshwater Science.

\section{LITERATURE CITED}

Alexander, R. B., R. A. Smith, and G. E. Schwarz. 2000. Effect of channel size on the delivery of nitrogen to the Gulf of Mexico. Nature 403:758-761.

Ashkenas, L. R., S. L. Johnson, S. V. Gregory, J. L. Tank, and W. M. Wollheim. 2004. A stable isotope tracer study of nitrogen uptake and transformation in an old-growth forest stream. Ecology 85:1725-1739.

Bernhardt, E. S., R. O. Hall, and G. E. Likens. 2002. Whole-system estimates of nitrification and nitrate uptake in streams at the Hubbard Brook Experimental Forest. Ecosystems 5:419-430.

Bernhardt, E. S., and G. E. Likens. 2002. Dissolved organic carbon enrichment alters nitrogen dynamics in a forest stream. Ecology 83:1689-1700.

Brookshire, E. N. J., L. O. Hedin, J. D. Newbold, D. M. Sigman, and J. K. Jackson. 2012. Sustained losses of bioavailable nitrogen from montane tropical forests. Nature Geoscience 5:123-126.

Brown, S., A. E. Lugo, S. Silander, and L. Liegel. 1983. Research history and opportunities in the Luquillo Experimental Forest. General Technical Report SO-44. US Department of Agriculture Forest Service, New Orleans, Louisiana.

Covino, T. P., B. L. McGlynn, and R. A. McNamara. 2010. Tracer additions for spiraling curve characterization (TASCC): quantifying stream nutrient uptake kinetics from ambient to saturation. Limnology and Oceanography: Methods 8:484-498. 
Cusack, D. F., J. Macy, and W. H. McDowell. 2016. Nitrogen additions mobilize soil base cations in two tropical forests. Biogeochemistry 128:67-88.

Day, N. K., and R. O. Hall. 2017. Ammonium uptake kinetics and nitrification in mountain streams. Freshwater Science 36:41-54.

Dodds, W. K., A. J. López, W. B. Bowden, S. Gregory, N. B. Grimm, S. K. Hamilton, A. E. Hershey, E. Martí, W. H. McDowell, J. L. Meyer, D. Morrall, P. J. Mulholland, B. J. Peterson, J. L. Tank, H. M. Valett, J. R. Webster, and W. Wollheim. 2002. N uptake as a function of concentration in streams. Journal of the North American Benthological Society 21:206-220.

Dodds, W. K., E. Martí, J. L. Tank, J. Pontius, S. K. Hamilton, N. B. Grimm, W. B. Bowden, W. H. McDowell, B. J. Peterson, H. M. Valett, J. R. Webster, and S. Gregory. 2004. Carbon and nitrogen stoichiometry and nitrogen cycling rates in streams. Oecologia 140:458-467.

Downing, J. A., M. McClain, R. Twilley, J. M. Melack, J. Elser, N. N. Rabalais, W. M. Lewis, Jr, R. E. Turner, J. Corredor, D. Soto, A. Yanez-Arancibia, J. A. Kopaska, and R. W. Howarth. 1999. The impact of accelerating land-use change on the N-cycle of tropical aquatic ecosystems: current conditions and projected changes. Biogeochemistry 46:109-148.

Earl, S. R., H. M. Valett, and J. R. Webster. 2006. Nitrogen saturation in stream ecosystems. Ecology 87:3140-3151.

Ensign, S. H., and M. W. Doyle. 2006. Nutrient spiraling in streams and river networks. Iournal of Geophvsical Research 111: G04009.

Fellows, C. S., H. M. Valett, C. N. Dahm, P. J. Mulholland, and S. A. Thomas. 2006. Coupling nutrient uptake and energy flow in headwater streams. Ecosvstems 9:788-804.

Gibson, C. A., C. M. O'Reilly, A. L. Conine, and S. M. Lipshutz. 2015. Nutrient uptake dynamics across a gradient of nutrient concentrations and ratios at the landscape scale. Journal of Geophysical Research: Biogeosciences 120:326-340.

González, G., and International Institute of Tropical Forestry. 2015. Bisley daily meteorologic data. University of Pennsylvania, Philadelphia, Pennsylvania. (Available from: https://www.sas .upenn.edu/lczodata/content/bisley-climate)

Hall, R. O., M. A. Baker, E. J. Rosi-Marshall, J. L. Tank, and J. D. Newbold. 2013. Solute-specific scaling of inorganic nitrogen and phosphorus uptake in streams. Biogeosciences 10:7323-7331.

Hall, R. O., E. S. Bernhardt, and G. E. Likens. 2002. Relating nutrient uptake with transient storage in forested mountain streams. Limnology and Oceanography 47:255-265.

Hall, R. O., and J. L. Tank. 2003. Ecosystem metabolism controls nitrogen uptake in streams in Grand Teton National Park, Wyoming. Limnology and Oceanography 48:1120-1128.

Hall, R. O., J. L. Tank, D. J. Sobota, P. J. Mulholland, J. M. O'Brien, W. K. Dodds, J. R. Webster, H. M. Valett, G. C. Poole, B. J. Peterson, J. L. Meyer, W. H. McDowell, S. L. Johnson, S. K. Hamilton, N. B. Grimm, S. V. Gregory, C. N. Dahm, L. W. Cooper, L. R. Ashkenas, S. M. Thomas, R. W. Sheibley, J. D. Potter, B. R. Niederlehner, L. T. Johnson, A. M. Helton, C. M. Crenshaw, A. J. Burgin, M. J. Bernot, J. J. Beaulieu, and C. P. Arango. 2009. Nitrate removal in stream ecosystems measured by $\mathrm{N}$ addition experiments: total uptake. Limnologv and Oceanographv 54:653-665.

Harvey, J. W., and B. J. Wagner. 2000. Quantifying hydrologic interactions between streams and their subsurface hyporheic zones. Pages 3-44 in J. B. Jones and P. J. Mulholland (editors).
Streams and groundwaters. Academic Press, San Diego, California.

Heartsill-Scalley, T., F. N. Scatena, C. Estrada, W. H. McDowell, and A. E. Lugo. 2007. Disturbance and long-term patterns of rainfall and throughfall nutrient fluxes in a subtropical wet forest in Puerto Rico. Journal of Hydrology 333(2-4):472-485.

Heartsill-Scalley, T., F. N. Scatena, S. Moya, and A. E. Lugo. 2012. Long-term dynamics of organic matter and elements exported as coarse particulates from two Caribbean montane watersheds. Journal of Tropical Ecology 28:127-139.

Helton, A. M., M. Ardón, and E. S. Bernhardt. 2015. Thermodynamic constraints on the utility of ecological stoichiometry for explaining global biogeochemical patterns. Ecology Letters 18:1049-1056.

Hoellein, T. J., J. L. Tank, E. J. Rosi-Marshall, S. A. Entrekin, and G. A. Lamberti. 2007. Controls on spatial and temporal variation of nutrient uptake in three Michigan headwater streams. Limnology and Oceanography 52:1964-1977.

Horton, R. E. 1945. Erosional development of streams and their drainage basins; hydrophysical approach to quantitative morphology. Geological Societv of America Bulletin 56:275-370.

Howarth, R. W., G. Billen, D. Swaney, A. Townsend, N. Jaworski, K. Lajtha, J. A. Downing, R. Elmgren, N. Caraco, T. Jordan, F. Berendse, J. Freney, V. Kudeyarov, P. Murdoch, and Z. ZhaoLiang. 1996. Regional nitrogen budgets and riverine $\mathrm{N}$ and $\mathrm{P}$ fluxes for the drainages to the North Atlantic Ocean: natural and human influences. Biogeochemistry 35:75-139.

Kilpatrick, F. A., and E. D. Cobb. 1985. Measurement of discharge using tracers. Chapter A16 in Techniques in Water Resources Investigations of the United States Geological Survey, book 3. US Government Printing Office, Washington, DC.

Leopold, L. B., and T. Maddock. 1953. The hydraulic geometry of stream channels and some physiographic implications. US Government Printing Office, Washington, DC.

Lewis, Jr, W. M., J. M. Melack, W. H. McDowell, M. McClain, and J. E. Richey. 1999. Nitrogen yields from undisturbed watersheds in the Americas. Biogeochemistry 46:149-162.

Matson, P. A., W. H. McDowell, A. R. Townsend, and P. M. Vitousek. 1999. The globalization of $\mathrm{N}$ deposition: ecosystem consequences in tropical environments. Biogeochemistry 46: $67-83$.

McDowell, W. H. 1998. Internal nutrient fluxes in a Puerto Rican rain forest. Journal of Tropical Ecology 14:521-536.

McDowell, W. H., W. B. Bowden, and C. E. Asbury. 1992. Riparian nitrogen dynamics in two geomorphologically distinct tropical rain forest watersheds: subsurface solute patterns. Biogeochemistry 18:53-75.

McDowell, W. H., and D. Liptzin. 2014. Linking soils and streams: response of soil solution chemistry to simulated hurricane disturbance mirrors stream chemistry following a severe hurricane. Forest Ecology and Management 332:56-63.

McDowell, W. H., C. P. McSwiney, and W. B. Bowden. 1996. Effects of hurricane disturbance on groundwater chemistry and riparian function in a tropical rainforest. Biotropica 28:577-584.

McDowell, W. H., F. N. Scatena, R. B. Waide, N. Brokaw, G. R. Camilo, A. P. Covich, T. A. Crowl, G. González, E. A. Greathouse, P. Klawinski, D. J. Lodge, A. E. Lugo, C. M. Pringle, B. A. Richardson, M. J. Richardson, D. A. Schaefer, W. L. Silver, J. Thompson, D. J. Vogt, K. A. Vogt, M. R. Willig, L. L. Woolbright, X. Zou, and J. K. Zimmerman. 2012. Geographic 
and ecological setting of the Luquillo Mountains. Pages 72-163 in: N. Brokaw, T. A. Crowl, A. E. Lugo, W. H. McDowell, F. N. Scatena, R. B. Waide, and M. W. Willig (editors). A Caribbean forest tapestry: the multidimensional nature of disturbance and response. Oxford University Press, New York.

Merriam, J. L., W. H. McDowell, J. L. Tank, W. M. Wollheim, C. L. Crenshaw, and S. L. Johnson. 2002. Characterizing nitrogen dynamics, retention and transport in a tropical rainforest stream using an in situ $\mathrm{N}$ addition. Freshwater Biology 47: 143-160.

Mulholland, P. J., A. M. Helton, G. C. Poole, R. O. Hall, S. K. Hamilton, B. J. Peterson, J. L. Tank, L. R. Ashkenas, L. W. Cooper, C. N. Dahm, W. K. Dodds, S. E. G. Findlay, S. V. Gregory, N. B. Grimm, S. L. Johnson, W. H. McDowell, J. L. Meyer, H. M. Valett, J. R. Webster, C. P. Arango, J. J. Beaulieu, M. J. Bernot, A. J. Burgin, C. L. Crenshaw, L. T. Johnson, B. R. Niederlehner, J. M. O'Brien, J. D. Potter, R. W. Sheibley, D. J. Sobota, and S. M. Thomas. 2008. Stream denitrification across biomes and its response to anthropogenic nitrate loading. Nature 452: 202205.

Murdock, J. N., and W. K. Dodds. 2007. Linking benthic algal biomass to stream substratum topography. Journal of Phycology 43:449-460.

Nash, J. C. 1990. Compact numerical methods for computers: linear algebra and function minimization. CRC Press, New York.

Neff, J. C., and G. P. Asner. 2001. Dissolved organic carbon in terrestrial ecosystems: synthesis and a model. Ecosystems 4:29-48.

Newbold, J. D., T. L. Bott, L. A. Kaplan, C. L. Dow, J. K. Jackson, A. K. Aufdenkampe, L. A. Martin, D. J. Van Horn, and A. A. Long. 2006. Uptake of nutrients and organic $C$ in streams in New York City drinking-water-supply watersheds. Iournal of the North American Benthological Society 25:998-1017.

Ortiz-Zayas, J. R., E. Cuevas, O. L. Mayo-Bracero, L. Donoso, I. Trebs, D. Figueroa-Nieves, and W. H. McDowell. 2006. Urban influences on the nitrogen cycle in Puerto Rico. Biogeochemistry 79:109-133.

Ortiz-Zayas, J. R., W. M. Lewis, Jr, J. F. Saunders, J. H. McCutchan, and F. N. Scatena. 2002. Metabolism of a tropical rainforest stream. Journal of the North American Benthological Society 24:769-783.

Parker, S. P., W. B. Bowden, and M. B. Flinn. 2016. The effect of acid strength and postacidification reaction time on the determination of chlorophyll $a$ in ethanol extracts of aquatic periphyton. Limnology and Oceanography: Methods 14:839-852.

Payn, R. A., M. N. Gooseff, B. L. McGlynn, K. E. Bencala, and S. M. Wondzell. 2009. Channel water balance and exchange with subsurface flow along a mountain headwater stream in Montana, United States. Water Resources Research 45:W11427.

Payn, R. A., J. R. Webster, P. J. Mulholland, H. M. Valett, and W. K. Dodds. 2005. Estimation of stream nutrient uptake from nutrient addition experiments. Limnology and Oceanographv: Methods 3:174-182.

Peterson, B. J., W. M. Wollheim, P. J. Mulholland, J. R. Webster, J. L. Meyer, J. L. Tank, E. Martí, W. B. Bowden, H. M. Valett, A. E. Hershey, W. H. McDowell, W. K. Dodds, S. K. Hamilton, S. Gregory, and D. D. Morrall. 2001. Control of nitrogen export from watersheds by headwater streams. Science 292: 86-90.

Pike, A. S., F. N. Scatena, and E. E. Wohl. 2010. Lithological and fluvial controls on the geomorphology of tropical montane stream channels in Puerto Rico. Earth Surface Processes and Landforms 35:1402-1417.

Potter, J. D., W. H. McDowell, J. L. Merriam, B. J. Peterson, and S. M. Thomas. 2010. Denitrification and total nitrate uptake in streams of a tropical landscape. Ecological Applications 20: $2104-2115$.

Riley, A. J., and W. K. Dodds. 2013. Whole-stream metabolism: strategies for measuring and modeling diel trends of dissolved oxygen. Freshwater Science 32:56-69.

Raymond, P. A., J. E. Saiers, and W. V. Sobczak. 2016. Hydrological and biogeochemical controls on watershed dissolved organic matter transport: pulse-shunt concept. Ecology 97:5-16.

Rodríguez-Cardona, B., A. S. Wymore, and W. H. McDowell. 2016. DOC: $\mathrm{NO}_{3}{ }^{-}$ratios and $\mathrm{NO}_{3}{ }^{-}$uptake in forested headwater streams. Iournal of Geophysical Research: Biogeosciences 121:205-217.

Runkel, R. L. 2007. Toward a transport-based analysis of nutrient spiraling and uptake in streams. Limnology and Oceanography: Methods 5:50-62.

Sartory, D., and J. Grobbelaar. 1984. Extraction of chlorophyll $a$ from freshwater phytoplankton for spectrophotometric analysis. Hydrobiologia 114:177-187.

Seitzinger, S., R. V. Styles, E. W. Boyer, R. B. Alexander, G. Billen, R. W. Howarth, B. Mayer, and N. Van Breemen. 2002. Nitrogen retention in rivers: model development and applications to watersheds in the northeastern U.S.A. Biogeochemistry 57: 199-237.

Silver, W. L., S. J. Hall, and G. González. 2014. Differential effects of canopy trimming and litter deposition on litterfall and nutrient dynamics in a wet subtropical forest. Forest Ecology and Management 332:47-55.

Silver, W. L., A. E. Lugo, and M. Keller. 1999. Soil oxygen availability and biogeochemistry along rainfall and topographic gradients in upland wet tropical forest soils. Biogeochemistry 44:301-328.

Sinsabaugh, R. L., and J. J. Follstad-Shah. 2012. Ecoenzymatic stoichiometry and ecological theory. Annual Review of Ecology, Evolution, and Systematics 43:313-343.

Snyder, L. E., and W. B. Bowden. 2014. Nutrient dynamics in an oligotrophic arctic stream monitored in situ by wet chemistry methods. Water Resources Research 50:2039-2049.

Soetaert, K., and F. Meysman. 2012. Reactive transport in aquatic ecosystems: rapid model prototyping in the open source software R. Environmental Modeling and Software 32:49-60.

Solórzano, L. 1969. Determination of ammonia in natural waters by the phenolhypochlorite method. Limnology and Oceanography 14:799-801.

Song, C., W. K. Dodds, M. T. Trentman, J. Rüegg, and F. Ballantyne. 2016. Methods of approximation influence aquatic ecosystem metabolism estimates. Limnology and Oceanography Methods 14:557-569.

Strauss, E. A., and G. A. Lamberti. 2000. Regulation of nitrification in aquatic sediments by organic carbon. Limnology and Oceanography 45:1854-1859.

Stream Solute Workshop. 1990. Concepts and methods for assessing solute dynamics in stream ecosystems. Journal of the North American Benthological Society 9:95-119.

Tank, J. L., and W. K. Dodds. 2003. Nutrient limitation of epilithic and epixylic biofilms in ten North American streams. Freshwater Biology 48:1031-1049. 
Tank, J. L., E. J. Rosi-Marshall, M. A. Baker, and R. O. Hall. 2008. Are rivers just big streams? A pulse method to quantify nitrogen demand in a large river. Ecology 89:2935-2945.

Trentman, M. T., W. K. Dodds, J. S. Fencl, K. Gerber, J. Guarneri, S. M. Hitchman, Z. Peterson, and J. Rüegg. 2015. Quantifying ambient nitrogen uptake and functional relationships of uptake versus concentration in streams: a comparison of stable isotope, pulse, and plateau approaches. Biogeochemistry 125:65-79.

Triska, F. J., A. P. Jackman, J. H. Duff, and R. J. Avanzino. 1994. Ammonium sorption to channel and riparian sediments: a transient storage pool for dissolved inorganic nitrogen. Biogeochemistry 26:67-83.

Uehlinger, U. 2000. Resistance and resilience of ecosystem metabolism in a flood-prone river system. Freshwater Biology 45:319-332.

Valett, H. M., J. A. Morrice, C. N. Dahm, and M. E. Campana. 1996. Parent lithology, surface-groundwater exchange, and nitrate retention in headwater streams. Limnology and Oceanography 41:333-345.

Webster, J. R., P. J. Mulholland, J. L. Tank, H. M. Valett, W. K. Dodds, B. J. Peterson, W. B. Bowden, C. N. Dahm, S. Findlay, S. V. Gregory, N. B. Grimm, S. K. Hamilton, S. L. Johnson, E. Martí, W. H. McDowell, J. L. Meyer, D. D. Morrall, S. A. Thomas, and W. M. Wollheim. 2003. Factors affecting ammo- nium uptake in streams - an inter-biome perspective. Freshwater Biology 48:1329-1352.

Webster, J. R., and H. M. Valett. 2006. Solute dynamics. Pages 169-185 in F. R. Hauer and G. A. Lamberti (editors). Methods in stream ecology. $2^{\text {nd }}$ edition. Academic Press, San Diego, California.

Wollheim, W. M., B. J. Peterson, L. A. Deegan, J. E. Hobbie, B. Hooker, W. B. Bowden, K. J. Edwardson, D. B. Arscott, A. E. Hershey, and J. Finlay. 2001. Influence of stream size on ammonium and suspended particulate nitrogen processing. Limnology and Oceanography 46:1-13.

Wollheim, W. M., B. J. Peterson, S. M. Thomas, C. H. Hopkinson, and C. J. Vörösmarty. 2008a. Dynamics of N removal over annual time periods in a suburban river network. Journal of Geophysical Research: Biogeosciences 113:G03038.

Wollheim, W. M., C. J. Vörösmarty, A. F. Bouwman, P. Green, J. Harrison, E. Linder, B. J. Peterson, S. P. Seitzinger, and J. P. M. Syvitski. 2008b. Global N removal by freshwater aquatic systems using a spatially distributed, within-basin approach. Global Biogeochemical Cycles 22:GB2026.

Wollheim, W. M., C. J. Vörösmarty, B. J. Peterson, S. P. Seitzinger, and C. S. Hopkinson. 2006. Relationship between river size and nutrient removal. Geophysical Research Letters 33:L06410. 